\title{
Unstacking the Deck: Administrative Summary Judgment and Political Control
}

\author{
Alexander I. Platt ${ }^{\dagger}$
}

The Administrative Procedure Act's provisions on formal adjudication give individuals charged in administrative enforcement actions the right to an in-person oral hearing. But not always. Agency prosecutors can circumvent formal hearing procedures without the consent of the defendant by resolving cases on "administrative summary judgment." A 1971 Harvard Law Review Article endorsed this procedure as a way for agency prosecutors to avoid "futile" hearings, and courts have upheld it based on the same technocratic justification. Yet administrative procedure is not merely an instrument to be expertly calibrated by administrators; it is a mechanism of political control. When Congress assigns enforcement of a given program to a formal adjudication regime, it is exercising its authority to "stack the deck," giving defendants access to elaborate procedural protections and limiting or channeling the enforcement program. Administrative summary judgment "unstacks the deck"-it unwinds Congress's procedural controls and allows an agency to recalibrate its enforcement priorities.

At the Securities and Exchange Commission, many administrative proceedings are now resolved on "summary disposition" without any in-person hearings. The recent expansion of summary dispositions has facilitated a broad shift in the agency's enforcement priorities toward easy-to-prosecute offenses, enabling the agency to show Congress a "record number of enforcement actions" year after year. That figure has (apparently) significant political value, but does not indicate anything about the effectiveness of the SEC's enforcement program.

Setting enforcement priorities is a critical function for agencies like the $S E C$ that are charged with enforcing a vast and complex array of legal obligations, but which have resources to pursue only a relatively small number of possible violations. Securities scholars have long debated the SEC's enforcement priorities, but have overlooked the role administrative

$\dagger \quad$ Associate, Boies, Schiller \& Flexner LLP. J.D., Yale Law School (2012). Law Clerk, Hon. Stephen F. Williams (D.C. Cir.) and Hon. Royce C. Lamberth (D.D.C.). Thanks to Ian Ayres, Yotam Barkai, Sean Childers, Tori Finkle, Abbe Gluck, Dan Hemel, Casey Hinkle, Robert Leider, Eric Merrill, Nick Parrillo, Richard Re, Roberta Romano, Susan Rose-Ackerman, Rory Skaggs, Chris Walker, and Urska Velikonja for comments. All views expressed here, along with any errors, are mine alone. Please send correspondence to alex.i.platt@gmail.com. 
adjudication procedure plays in shaping those priorities-as both a vehicle for congressional control and administrative rebellion.

Introduction 440

I. Two Theories of Administrative Summary Judgment.

A. The Consensus Justification for Administrative Summary Judgment....

B. Challenging the Consensus Justification ...................................445

C. Administrative Summary Judgment as Unstacking the Deck .....448

D. The Two Theories Compared and Reconciled. 454

II. Indicia of Unstacking

III. Case Study: SEC Summary Disposition 461

A. The Rise of SEC Summary Disposition....................................464

B. SEC Summary Disposition: The Consensus Justification...........469

C. SEC Summary Disposition: Unstacking the Deck...................470

IV. Implications 483

A. Scholars

B. Courts 485

C. $A L J s$.... 487

D. Congress 487

E. Agencies. 488

F. The SEC.

Conclusion

Introduction

The APA's provisions on formal adjudication ordinarily guarantee a triallike hearing. ${ }^{1}$ The respondent appears in person before an ALJ in a courtroom, or court-like setting. His lawyer can cross-examine the government's witnesses and present evidence. And he can take the stand himself to assert his innocence, or beg forgiveness.

But not always. Agency enforcers can dispense with the full-blown hearing and obtain a quick and easy victory by persuading an ALJ to resolve a case on summary judgment. Once rare, these motions are now frequently used by agencies to skip over administrative hearings without the defendants' consent. The intellectual foundation for this development comes out of a 1971 Harvard Law Review Article. ${ }^{2}$ The authors, presenting the results of a study

1. See, e.g, 1 KENNETH CUlP Davis, AdMinistrative LaW Treatise 408 (1958); see also 5 U.S.C. $\S \S 554,556$; Jerry L. MASHAw, Richard A. MERriLl, \& PETER M. Shane, AdMinistrative LAW: THE AMERICAN PUBLIC LAW SySTEM 423 (6th ed. 2009).

2. Ernest Gellhorn \& William F. Robinson, Summary Judgment in Administrative Adjudication, 84 HARV. L. REV. 612 (1971). 
sponsored by the Administrative Conference of the United States, argued that the statutory right to a hearing should not bar summary judgment because the right does not apply to "futile" hearings. Agencies and courts have embraced this justification and administrative summary judgment has quietly become a powerful tool for administrative enforcers.

This broad consensus supporting administrative summary judgment is not well-founded. Administrative procedure is not only an instrument to be expertly calibrated to implement the underlying program with maximum efficiency, it is also an instrument of political control. When Congress delegates implementation of a program to an administrative agency, it can design administrative procedures that "stack the deck" in favor of a particular constituency to ensure that the agency's implementation will remain faithful to Congress's intentions for the program. ${ }^{3}$ When Congress requires a full hearing before an agency can impose certain penalties, this has the effect of limiting and channeling that agency's enforcement program and priorities. By dispensing with this hearing requirement, administrative summary judgment unstacks the deck, removing the enforcement controls imposed by Congress, and facilitating "drift" away from the enacting Congress's plans for the enforcement program.

A study of the Securities and Exchange Commission's use of this technique highlights the shortcomings of the consensus justification for administrative summary judgment. The SEC's administrative adjudication regime has been the subject of recent scrutiny, ${ }^{4}$ but critics have overlooked the agency's expansive use of motions for "summary disposition." A close study reveals that for SEC prosecutors this procedure is not merely a tool used to skip over "futile" hearings as they happen to arise. Rather, the procedure is itself shaping the agency's enforcement priorities, steering it towards certain types of cases and defendants. In other words, the ability to dispense with the full hearings originally required by Congress has led to securities enforcement "drift."

The federal securities laws impose a vast (and expanding) array of legal obligations on issuers, exchanges, underwriters, corporate insiders, hedge funds, brokers, dealers, lawyers, accountants, and many others. The scope and complexity of these obligations ensures that the volume of potential violations easily outstrips the resources available to the SEC to pursue them. ${ }^{5}$ Accordingly, the agency is forced to make programmatic choices about which cases it will pursue, which obligations it will enforce, and which actors it will

3. See infra Section I.B. In this context, "stacking the deck" is not a pejorative.

4. See, e.g., Alexander I. Platt, SEC Administrative Proceedings: Backlash and Reform, 71 BUS. LAW. 1 (2016); see also infra text accompanying notes 97-106 (reviewing recent studies of SEC enforcement).

5. E.g., Donald C. Langevoort, Selling Hope, Selling Risk: Corporations, WALl STREET, AND THE DILEMMAS OF INVESTOR PROTECTION 46 (2016) ("[T] he SEC has been forced to live in relative poverty given what is being asked of it."). 
investigate - and which not. These enforcement priorities become a fundamental component of the regulatory landscape. Investors and the voting public count on the SEC to choose its enforcement priorities wisely and in the public interest. The regulated industry (along with the defense bar) pays close attention whenever the SEC announces a new enforcement initiative or brings a new type of case. ${ }^{6}$

Given the significance of these decisions, it is unsurprising that SEC's enforcement priorities seem to be the source of perpetual controversy. To date, however, the SEC's critics and defenders alike have overlooked administrative adjudication procedure as a factor driving the agency's enforcement priorities and as a mechanism by which Congress asserts control over these priorities. The same is true of administrative law scholars more generally. ${ }^{8}$ The paper aims to help correct this oversight.

This Article proceeds in four Parts. Part I reviews the consensus justification for administrative summary judgment, surveys the inadequacies in this justification, and provides an alternative theoretical lens-"unstacking the deck"-which treats administrative summary judgment as an instrument of political control. Part II elaborates and develops an indirect "test" for these two competing theories, and Part III applies this test to a case study of the SEC's summary disposition program. Part IV reviews the implications of this new lens for scholars, and offers recommendations for how agencies, courts, and Congress should adjust their approaches to administrative summary judgment.

\section{Two Theories of Administrative Summary Judgment}

This Part presents two competing modes of analysis of administrative summary judgment. It begins by exploring the intellectual foundation for the broad contemporary acceptance of the procedure-what I call the "Consensus Justification." It then criticizes this justification, and presents an alternative"Unstacking the Deck." Finally, it compares the two theories.

\section{A. The Consensus Justification for Administrative Summary Judgment}

Until the early 1970s, very few agencies used administrative summary judgment. ${ }^{9}$ This began to change after the publication of an article by Ernest Gellhorn and William Robinson in the Harvard Law Review in 1971. The Article, presenting the results of a study sponsored by the Administrative Conference of the United States, urged agencies to "take a leaf from the federal

\footnotetext{
6. See infra note 33 .

7. See infra text accompanying notes 104-106 (surveying recent empirical studies of SEC enforcement).

8. See infra text accompanying notes 211-223 (surveying recent literature on administrative enforcement).

9. Gellhorn \& Robinson, supra note 2, at 621-22.
} 
rules of civil procedure" and utilize administrative summary judgment "to reduce delay." They argued that the statutory right to a hearing was no obstacle because "statutory . . . rights to a hearing should not be interpreted as prohibiting the use of summary judgment by an agency to eliminate futile evidentiary hearings." 10 The right to a hearing could be properly dispensed with, therefore, in those cases where "the absence of a hearing could not affect the decision," 11 and "when the papers filed with the motion clearly reveal that an evidentiary hearing would serve no useful purpose."12

Armed with a justification for dispensing with statutory hearing rights, agencies embraced administrative summary judgment. And, when challenged, Courts upheld it based on the same rationale. ${ }^{13}$ D.C. Circuit Judge Harold Leventhal framed the point most colorfully: "[T]he right of opportunity for hearing does not require a procedure that will be empty sound and show, signifying nothing." 14 Others invoked similar logic, concluding that holding a statutory hearing that would not enhance the accuracy of the outcome would be "strange," a "waste of time,", would defy "common sense,"17 and "serve no useful purpose,", and so such a design "cannot [be] impute[d] to Congress.",

10. Id. at 620 .

11. Id at 617 .

12. Id. at 616 .

13. See Costle v. Pac. Legal Found, 445 U.S. 198, 215 (1980) (rejecting the requirement of a hearing in all cases except where the agency demonstrates a lack of genuine issue of material fact because this procedural requirement would "raise serious questions about the EPA's ability to administer the ... program"); Nat'l Indep. Coal Operators' Assn. v. Kleppe, 423 U.S. 388, 399 (1976) (upholding regulations which keyed the statutory requirement of a hearing to a request for such a hearing in part where "[e]ffective enforcement of the Act would be weakened if the Secretary were required to make findings of fact for every penalty assessment including those cases in which the mine operator did not request a hearing and thereby indicated no disagreement with the Secretary's proposed determination"); Weinberger v. Hynson, Wescott \& Dunning, Inc., 412 U.S. 609, 621 (1973) ("If FDA were required automatically to hold a hearing for each product ... even though many hearings would be an exercise in futility, we have no doubt that it could not fulfill its statutory mandate ...."); Puerto Rico Aqueduct \& Sewer Auth. v. EPA, 35 F.3d 600, 605-07 (1st Cir. 1994) ("[S]ummary judgment often makes especially good sense in an administrative forum, for, given the volume of matters coursing through an agency's hallways, efficiency is perhaps more central to an agency than to a court.").

14. Citizens for Allegan Cty., Inc. v. FPC, 414 F.2d 1125, 1128 (D.C. Cir. 1969).

15. Crestview Parke Care Ctr. y. Thompson, 373 F.3d 743, 750 (6th Cir. 2004).

16. United States v. Storer Broad. Co., 351 U.S. 192, 205 (1956).

17. Veg-Mix, Inc. v. U.S. Dep't of Agric., 832 F.2d 601, 607 (D.C. Cir. 1987).

18. Hess \& Clark v. FDA, 495 F.2d 975, 985 (D.C. Cir. 1974).

19. Weinberger v. Hynson, Wescott \& Dunning, Inc., 412 U.S. 609, 623 (1973); see also Puerto Rico Aqueduct \& Sewer Auth. v. EPA, 35 F.3d 600, 606 (1st Cir. 1994) ("Due process simply does not require an agency to convene an evidentiary hearing when it appears conclusively from the papers that, on the available evidence, the case only can be decided one way." (emphasis added)); Burnele V. Powell, Administratively Declaring Order: Some Practical Applications of the Administrative Procedure Act's Declaratory Order Process, 64 N.C. L. REV. 277, 284 (1986) ("No good reason exists for proceeding with a formal hearing in the absence of any genuine issue of material fact."); id. at 282 (administrative summary judgment "ensures that neither members of the public nor federal agencies are allowed to gain unfair advantages as a result of meaningless procedural steps" (emphasis added)); $R$. Cameron Turner, Note, Streamlining EPA's NPDES Permit Program With Administrative Summary Judgment: Puerto Rico Aqueduct \& Sewer Authority v. Environmental Protection Agency, 26 ENVTL. L.J. 729, 730 (1996) (noting that administrative summary judgment can "effectively resolve disputes without expending valuable agency resources or infringing on a party's statutory right to a hearing"). 
This Consensus Justification for administrative summary judgment implicitly reflects the logic of Economic Analysis of Civil Procedure. Judge Posner set the terms in 1973, articulating the goal of procedure as the minimization of the sum of "error costs" and "direct costs." 20 Though "error costs" is a capacious term, encompassing all social costs imposed by the adjudication, Posner traced these costs to "judicial error"-i.e., inaccurate adjudication. ${ }^{21}$ Others have followed this approach, emphasizing the tradeoff between procedural cost and outcome accuracy. ${ }^{22}$ Reframed in these terms, the Consensus Justification for administrative summary judgment embraces that procedure as a way to avoid costly hearings wherever the benefits (reduced procedural costs) outweigh the costs (inaccuracy). ${ }^{23}$

In adopting this technocratic framework to justify administrative summary judgment, these scholars and courts are in good company. The Supreme Court has adopted this approach in the context of procedural due process, defining constitutionally mandated procedures as a function of "the risk of an erroneous deprivation of [the private] interest through the procedures used, and the probable value, if any, of additional or substitute procedural safeguards" and "the Government's interest, including the function involved and the fiscal and administrative burdens that the additional or substitute procedural requirement would entail." 24 Much of the legal literature on administrative procedure adopts a similar mode of analysis. ${ }^{25}$ And parts of the APA also seem to embody this view. Section 556(d) provides individuals in formal adjudications with the right

\footnotetext{
20. Richard A. Posner, An Economic Approach to Legal Procedure, 2 J. LEGAL STUD.

399 (1973).

21. Id. at 401 ("[R]eduction of error is a goal of the procedural system" because such error is a "source of social costs."); see also George J. Stigler, The Optimum Enforcement of Laws, in ESSAYS IN THE ECONOMICS OF CRIME AND PUNISHMENT 56 (Gary S. Becker \& William Landes, eds. 1974) ("There is one decisive reason why the society must forego "complete' enforcement of the rule: enforcement is costly.").
}

22. Daniel Klerman, The Economics of Civil Procedure, 11 ANN. REV. OF L. \& SOC. $\mathrm{SCl}$. 353, 354 (defining "error costs" as efficiency losses caused by "inaccurate adjudication"). For a more nuanced view, see Louis Kaplow \& Stephen Shavell, Fairness Versus Welfare, 114 HARV. L. REV. $961,1186-87 \&$ n.536 (2001) ("Legal procedures that produce more accurate outcomes typically will lead to more desirable behavior" but "[ $[\mathrm{w}] \mathrm{e}$ do not mean to suggest that effects on accuracy are the only relevant features of procedure besides cost.").

23. Klerman, supra note 22, at 355 ("By terminating cases early, [dispositive motions] reduce direct costs, such as the cost of discovery and trial. Whether they increase error costs depends on the standards used. If motions are granted only when the probability that the plaintiff would prevail at trial is zero or very low, then motions increase error costs by little or nothing.").

24. Mathews v. Eldridge, 424 U.S. 319 (1976); see also Jerry Mashaw, The Supreme Court's Due Process Calculus for Administrative Adjudication: Three Factors in Search of a Theory of Value, 44 U. CHI. L. REV. 28 (1978).

25. See Matthew D. McCubbins, Roger G. Noll \& Barry R. Weingast, Structure and Process, Politics and Policy: Administrative Arrangements and the Political Control of Agencies, 75 VA. L. REV. 431, 443 (1989) (stating that the literature on administrative law and organizational design "deals with achieving efficient outcomes within a process that protects the rights of people who are likely to be affected by a policy decision"); Lisa Schultz Bressman, Procedures as Politics in Administrative Law, 107 COLUM. L. REV. 1749, 1751 (2007) ("Legal scholars are largely united in a general obsession with the Supreme Court's role in enhancing the legitimacy of agency action, for example, by announcing rules that promote due process or political accountability."). 
to cross-examine the government's witnesses, but only "such . . . as may be required for a full and true disclosure of the facts." 26 Hearing officers may allow depositions "when the ends of justice would be served."27 Costly procedures may be dispensed with where they would not enhance accuracy. ${ }^{28}$

In addition, courts that have upheld administrative summary judgment have also drawn on, and expanded Gellhorn and Robinson's analogy to summary judgment in the civil context. One court explained: "Given that federal district courts can decide cases as a matter of law without an oral hearing when it is clear there are no genuine material disputes to be resolved in a trial, it would be bizarre if administrative agencies, which are in many respects modeled after the federal courts and which indeed often have more informal proceedings than federal courts, could not follow a similar rule."29 Another explained: "[S]ummary judgment is less jarring in the administrative context; after all, even under optimal conditions, agencies do not afford parties full-dress jury trials.",30

\section{B. Challenging the Consensus Justification}

For decades, agencies have developed the practice of administrative summary judgment, and courts have upheld it, based on the intellectual foundation laid by Gellhorn and Robinson. But this foundation cannot support that weight.

First, the Consensus Justification entirely overlooks agencies' most important enforcement decisions. It is focused on the individual case level, asking whether a hearing would be futile in a particular case. ${ }^{31}$ But agencies also set enforcement priorities; they decide which types of cases and defendants to pursue, and which not. ${ }^{32}$ And these priority-setting decisions are a critical part of the regulatory landscape; regulated industries pay close

26. 5 U.S.C. $\$ 556(\mathrm{~d})$.

27. 5 U.S.C. $\$ 556(\mathrm{c})(4)$.

28. One critical factor in the economic analysis of procedure not specifically addressed in this discussion is the magnitude of the consequences of the adjudication. The higher the stakes, the more procedural costs may be justified - even assuming limited gains in accuracy. This logic has an uneasy fit with the legal realities of procedures designed to be trans-substantive. Cf. Robert $\mathrm{M}$. Cover, For James Wm. Moore: Some Reflections on a Reading of the Rules, 84 Y ALE L.J. 718 (1975).

29. Crestview Parke Care Ctr. v. Thompson, 373 F.3d 743, 750 (6th Cir. 2004).

30. Puerto Rico Aqueduct \& Sewer Auth. v. EPA, 35 F.3d 600, 606 (1st Cir. 1994); see also Weinberger v. Hynson, Wescott \& Dunning, Inc., 412 U.S. 609, 621 (1973) ("If this were a case involving trial by jury as provided in the Seventh Amendment, there would be sharper limitations on the use of summary judgment.").

31. See supra Section I.A.

32. See, e.g., Margaret H. Lemos, Accountability and Independence in Public Enforcement 3 (Duke Law Sch. Public Law \& Legal Theory Series, Paper No. 2016-23, 2016), http://ssrn.com/abstract=2748720 ("No government enforcers-at least not in the U.S.-have the resources to pursue every possible violation of the law. They have to pick and choose, to set priorities and goals."); Rachel E. Barkow, Overseeing Agency Enforcement, Foreword, Annual Review of Administrative Law, 84 GEO. WASH. U. L. REV. 1129, 1131 (2016) ("[E]nforcement discretion is far broader than a decision to move ahead against a party."). 
attention to even subtle signals from an agency about the direction of its enforcement program. ${ }^{33}$ It seems plausible that a switch from a full-blown hearing to administrative summary judgment might have some sort of impact on these programmatic enforcement decisions, but the Consensus Justification sidesteps the question.

Second, the Consensus Justification relies exclusively on a technocratic tradeoff between accuracy and the costs of adjudication; when a costly hearing would not enhance accuracy, the agency can skip it, regardless of what the statute says. ${ }^{34}$ But accuracy and cost are not the only values embodied in administrative procedure. When Congress selects procedures that an agency must follow when implementing a legislative program, Congress may be furthering a diversity of ends, just as when it passes substantive legislation. ${ }^{35}$ The Consensus Justification fails to provide any account for any values other than the cost/accuracy tradeoff that may be motivating Congress's procedural choices.

Third, the Consensus Justification vests substantial authority in administrative prosecutors to calculate whether or not a full hearing is required. ${ }^{36}$ But there are reasons to doubt that these prosecutors will make this calculation correctly. Administrative prosecutors have an interest in promoting the cost-saving summary judgment procedure. The fact that they appear in every case may create a repeat player effect, and give them the ability to "play for the rules" - that is, select cases strategically to advance more permissive rulings on the availability of administrative summary judgment. ${ }^{37}$ The ALJs who review these judgments may not exercise adequate controls; they may be

33. E.g., Kate Andrias, The President's Enforcement Power, 88 N.Y.U. L. REV. 1031, 1042-46 (2013); Lemos, supra note 32, at 17-19 (explaining "the functional equivalence of regulation and enforcement").

34. See supra Section I.A.

35. See infra Section I.C.

36. See supra Section I.A.

37. Marc Galanter, Why the "Haves" Come Out Ahead: Speculations on the Limits of Legal Change, 9 L. \& SoC'Y REV. 95 (1974); see also Lisa B. Bingham, Employment Arbitration: The Repeat Player Effect, 1 EMP. RTS. \& EMP. POL'Y J. 189 (1997); Eric A. Posner, Law, Economics, and Inefficient Norms, 144 U. PA. L. REV. 1697, 1704 (1996) ("[A]ctors who benefit more from inefficient rules than from efficient rules have every incentive to litigate the latter while settling disputes arising under the former .... [There is] ample reason to belicve that repeat players can exploit the institutional constraints binding courts in order to effect doctrinal changes that redistribute wealth to them.").

Galanter focused on ordinary civil litigation where certain parties tend to appear in different cases in similar roles. Others have developed the argument further-tracing certain developments in civil procedure to the strategic advantages of "repeat players." See Arthur R. Miller, From Conley to Twombly to Iqbal: A Double Play on the Federal Rules of Civil Procedure, 60 DUKE L.J. 1 (2010) (discussing motions to dismiss); Samuel Issacharoff \& George Loewenstein, Second Thoughts about Summary Judgment, 100 YALE L.J. 73 (1990) (summary judgment); see also Judith Resnik, Mediating Preferences: Litigant Preferences for Process and Judicial Preferences for Settlement, 2002 J. DISP. RESOL. 155, 166-67 (2002) ("Procedural rulemaking has become another arena to be captured by institutional interests. The effects of repeat-player defendants have been tracked in the limitations imposed on discovery and in the promotion of non-court based decisionmaking."). There is an even stronger basis to suppose it is true in the administrative context, where the government always appears in the same role. 
biased in favor of the agencies who employ them and may view the lawyers who prosecute cases as colleagues. ${ }^{38}$

Fourth, the Consensus Justification relies on an analogy between administrative and civil variants of summary judgment that is facile and misleading. ${ }^{39}$ For one thing, the purposes underlying civil and administrative procedure are not the same. As discussed more fully in the following section, Congress sets administrative procedures to control the bureaucracy, a purpose without direct parallel in the civil litigation context. ${ }^{40}$ Further, some features of administrative adjudication call for more protective procedures than civil litigation, not less: as just discussed, administrative prosecutors may have the incentive and ability to push for more permissive summary judgment. Article III judges might well be reasonably trusted to wield the power of summary judgment, which requires making a decision with less information than after a full-blown hearing, without entailing that ALJS be similarly trusted. ${ }^{41}$ Moreover, parties subjected to formal APA hearings do not have access to the full panoply of discovery rights, and without effective discovery, a party opposing an agency's motion for summary judgment is at a disadvantage.

38. For skeptical views of ALJ independence, see Jed S. Rakoff, Speech Before the Practicing Law Institute: Is the S.E.C. Becoming a Law Unto Itself? (Nov. 5, 2014); Kent Barnett, Resolving the ALJ Quandary, 66 VAND. L. REV. 797, 799 (2013); Antonin Scalia, The ALJ Fiasco-A Reprise, 47 U. CHI. L. REV. 57 (1979); Cf. USV Pharm. Corp. v. Sec'y of Health, Educ. and Welfare, 466 F.2d 455, 461 (D.C. Cir. 1972) (suggesting that "[a] vital distinction" between administrative summary disposition and FRCP 56 "is that the Commissioner here was not an impartial arbiter of the contentions of opposing parties, but was himself the moving party undertaking to support his own proposed order"). For discussion of particular evidence of ALJ bias inside the SEC, see infra note 205.

39. See supra Section I.A.

40. See infra Section I.C.

41. See supra note 205 (discussing evidence of ALJ bias).

42. See MASHAW, ET AL., supra note 1, at 425 (citing 5 U.S.C. § 555(c)) (explaining that the APA is "all but silent" on the topic of discovery, indicating only that subpoenas and other investigative measures may be available "as authorized by law."); cf. 16 C.F.R. $\S 3.33$ (2016) (FTC permits depositions); Amendments to the Commission's Rules of Practice, 80 Fed. Reg. 60,091 (Oct. 5, 2015) (SEC proposing to allow depositions); Citizens Awareness Network, Inc. v. United States, 391 F.3d 338 (1st Cir. 2004) (reviewing Nuclear Regulatory Commission moving away from depositions). Indeed, early proposals to adapt summary judgment to the administrative context were explicitly limited to those agencies that provided for effective discovery. Admin. Conf. of the United States, Summary Decision in Agency Adjudication, Recommendation No. $70-3$ (June 3, 1970); Gellhorn \& Robinson, supra note 2 , at 618 .

The SEC recently promulgated changes to its rules of practice to allow for a limited number of depositions by respondents in Administrative Proceedings. Amendments to the Commission's Rules of Practice, Final Rules, 112-13, SEC Release No. 34-78319, 81 Fed. Reg. 50,212 (July 13, 2016); see also infra notes $135-136$ (discussing these rule changes).

At the same time, respondents in administrative proceedings have at least one procedural protection that many civil litigants lack: the controls that operate on government enforcement agencies governing the decision to file charges. Michael Asimow, Five Models of Administrative Adjudication, 63 AM. J. COMP. L. 3, 5 n.8 (2015); see also Ray Garrett, S.E.C. Chairman, Address at Southwestern Legal Foundation, A Look at the SEC'S Administrative Practice, Speech to SW Legal Foundation (Apr. 25, 1974) ("SEC administrative proceedings are seldom begun on a mere hunch ...."). In some cases, this involves an airing of the possible charges before they are filed and a chance for the putative respondent to refute them. E.g., 17 C.F.R. $\S 202.5$ (c) ("Persons who become involved in ... [SEC] investigations may ... submit a written statement to the Commission setting forth their interests and position in regard to the subject matter of the investigation."). By contrast, civil defendants may be subjected to all sorts of 
Finally, the analogy to the civil motion fails because enforcement proceedings often bear a closer resemblance to criminal prosecutions than civil proceedings. ${ }^{43}$ While ALJs do not have the power to incarcerate, they do hand out significant penalties, ${ }^{44}$ including (in the case of the SEC), lifetime bars from an entire area of the economy. For criminal sentencings, most jurisdictions recognize defendant's right of allocution. ${ }^{45}$ Depriving an administrative defendant of his statutory right to face the judge who will impose his "sentence" conflicts with broadly accepted norms. ${ }^{46}$

The broad embrace of administrative summary judgment by scholars, courts, and agencies thus rests on a faulty foundation. To account for the issues ignored by the Consensus Justification, the next section considers administrative summary judgment through an alternative theoretical lens.

\section{Administrative Summary Judgment as Unstacking the Deck}

Since the late 1980s, scholars have developed a theory of administrative procedure as a mechanism of political control. ${ }^{47}$ When Congress delegates enforcement to an administrative agency, it understands that the agency may not adhere to its views and that future congressional oversight may push the agency in different directions. The enacting Congress is aware of the risk of "drift," and wants to do what it can to lock in its intentions for the enforcement program. $^{48}$

One way Congress achieves this control is by using administrative procedures to "stack the deck," steering regulation in a particular direction by

frivolous, unintelligent, and baseless suits from private parties. (When the SEC prosecutes someone in federal court, that person is similarly entitled to the Wells Process. But FRCP 56 is calibrated to all civil litigation, not just those cases in which the government is the plaintiff.)

43. E.g., Steven R. Glaser, Statutes of Limitations for Equitable and Remedial Relief in SEC Enforcement Actions, 4 HARV. BUS. L. REV. 129, 130-31 (2014).

44. The SEC would object to the terminology "penalty." Officially, bars are supposed to be "remedial," not punitive.

45. 6 WAYNe LaFAVE ET AL., CRIM. PROC. $\$ 26.4$ (g) (3d ed.) (collecting sources).

46. Cf., e.g., Arthur F. Matthews, Litigation and Settlement of SEC Administrative Proceedings, 29 CATH. U. L. REV. 215, 259-60 (1980) ("Since the Commission must tailor its sanction to comply with public interest criteria, character witness testimony can constitute a crucial underpinning of a respondent's trial strategy. In this respect, trial of the administrative proceeding resembles criminal litigation much more than routine civil litigation.").

47. See Jonathan R. Macey, Organizational Design and Political Control of Administrative Agencies, 8 J. L. ECON. \& ORG. 93 (1992); McNollgast, Administrative Procedures as Instruments of Political Control, 3 J. L. ECON. \& ORG. 243 (1987). For key elaborations, see McNollgast, Structure and Process, supra note 25. For applications, see for instance, Bressman, supra note 25; Daniel A. Farber, Politics and Procedure in Environmental Law, 8 J. L. ECON. \& ORG. 59 (1992); James T. Hamilton \& Christopher H. Schroeder, Strategic Regulators and the Choice of Rulemaking Procedures: The Selection of Formal vs. Informal Rules in Regulating Hazardous Waste, 57 L. \& CONTEMP. PROBS. 111 (1994); and McNollgast, The Political Origins of the Administrative Procedure Act, 15 J. L. ECON. \& ORG. 180 (1999).

48. See sources cited, supra note 47. 
building in a significant role for a particular interest group or constituency. ${ }^{49}$ This method is decentralized, relying on constituents and judicial review, rather than future Congressional oversight. ${ }^{50}$ This decentralization is an important advantage, since the enacting Congress obviously cannot rely on future Congresses to enact its own vision of administrative oversight.

The procedural requirement of a full hearing is a form of deck-stacking that can limit or channel enforcement programs. An agency's level of enforcement is limited by, among other things, the agency's budget, the

49. "[T] he point of [deck-stacking] administrative procedures is not to preselect specific policy outcomes, but to create a decisionmaking environment that mirrors the political circumstances that gave rise to the establishment of the policy. Whereas political officials may not know what specific policy outcome they will want in the future, they will know which interests ought to influence a decision and what distributive outcomes will be consistent with the original coalitional arrangement." McNollGast, Administrative Procedures, supra note 37, at 255. One McNollgast skeptic listed the following examples of deck-stacking techniques: "mandatory consultation by the agency with carefully constituted advisory committees or scientific panels; subjecting the agency to exogenous control over its agenda"; requirements to produce impact statements"; "elaborate cost-benefit or regulatory analyses before taking action"; "subsidies or cost reimbursements to certain kinds of participants"; "legislative vetoes"; and "mandatory submission of a proposed rule to legislative committees or to the drafters of the original bills." Michael Asimow, On Pressing McNollGast to the Limits: The Problem of Regulatory Costs, 57 L. \& CONTEMP. PROBS., 127, 132 (1994).

Other procedures can facilitate "fire alarm" oversight, enabling constituencies bring information about the bureaucracy to Congressional overseers before it becomes "fait accompli." See Mathew D. McCubbins \& Thomas Schwartz, Congressional Oversight Overlooked: Police Patrols versus Fire Alarms, 28 AM. J. POL. SCI. 165, 166 (1984) ("[I]nstead of examining a sample of administrative decisions, looking for violations of legislative goals, Congress establishes a system of rules, procedures, and informal practices that enable individual citizens and organized interest groups to examine administrative decisions (sometimes in prospect), to charge executive agencies with violating congressional goals, and to seek remedies from agencies, courts, and Congress itself."); see also McNollgast, Structure and Process, supra note 25, at 434 ("A fire alarm converts the oversight job of a politician from active monitor to reactive servant of affected constituencies."). Per McNollgast, the APA allows an agency's attempts to alter policy "to be spotted earlier by constituents, giving political officials more time to impose sanctions on errant bureaucrats." McNollGast, Administrative Procedures, supra note 37, at 259-60; see also id. at 258 (noting that the APA's rulemaking requirements "ensure that agencies cannot secretly conspire against elected officials by presenting them with a fait accompli, that is, a new policy with already mobilized supporters"); Macey, Organizational Design, supra note 47, (stating that the extra delay created by certain procedures provides a particular advantage to certain constituencies).

The theory has been influential, though it has also been challenged on both theoretical and empirical grounds. See, e.g., Bressman, supra note 25, at 1752 (criticizing the PPT theory as relying on a "simplistic" understanding of the role of the Court in the administrative procedure system); Asimow, supra note 49 , at 131 ("[W] the fire will be doused (or fed or ignored) by the existing power balance in the legislature rather than by the coalition that existed at the time the legislation was enacted."). For McNollgast's response to Bressman, see McNollgast \& Daniel B. Rodriguez, Administrative Law Agonistes, 108 CoLUM. L. REV. SIDEBar 15 (2008). E.g., Steven J. Balla, Administrative Procedures and Political Control of the Bureaucracy, 92 AM. POL. SCI. REV. 663, 669-71 (1998) (finding that notice-and-comment process did not support deck-stacking theory). See also Bressman, supra note 25, at 1770 n. 127 (collecting empirical challenges to deck-stacking).

50. "Procedures will only have their desired effect if their requirements are enforced

The courts thus play a key role in assuring political control .... Put another way, enforcement of procedures is decentralized in that enforcement does not depend on the action of political principals." McNollgast, Administrative Procedures, supra note 37, at 263; but see Bressman, supra note 25, at 1771 (finding that PPT scholars "have been unable to determine whether the Court has implemented Congress's theoretical controls"). 
substantive law, the agency's priorities, and the costs of enforcement. ${ }^{51}$ Administrative procedures factor into the costs of enforcement; more costly adjudicatory procedures require the agency to allocate more resources towards each enforcement action. ${ }^{52}$ Assuming a fixed budget, raising the cost of an individual enforcement action will limit the number of actions the agency pursues, or will channel its enforcement priorities in some way. ${ }^{53}$

Suppose Congress is considering a new program and is divided on the merits. Factions might reach a compromise (e.g., in the context of broader legislative package) under which the contested program will be enacted subject to limits on the level of enforcement. Giving expansive procedural rights to defendants is one way congressional opponents could give effect to their skeptical view of the underlying program.

Or, suppose Congress is united on the merits of the substantive program, but wants to ensure that the agency concentrates its enforcement resources on the most serious offenses and the most significant defendants. By imposing costly procedures, Congress may hope to channel enforcement towards more high-impact or high-stakes actions, where the benefits to the agency of a victory are worth the high procedural costs, and away from low-impact ones, which will not be worth the agency's time.

Viewed through this theoretical lens, administrative summary judgment "unstacks the deck." By allowing the agency to circumvent the full hearing that was required by Congress to limit or channel its enforcement program, summary judgment facilitates a shift in that program and "drift" from the plans of the original legislative coalition. ${ }^{54}$

51. E.g., James D. Cox \& Randall S. Thomas, SEC Enforcement Heuristics: An Empirical Inquiry, 53 DUKE L.J. 737, 751-53 (2003); U.S. GOV'T ACCOUNTABILITY OFF., GAO 07-830, SECURITIES EXCHANGE COMMISSION: ADDITIONAL ACTIONS NEEDED TO ENSURE PlaNNED IMPROVEMENTS ADDRESS LIMITATIONS IN ENFORCEMENT DIVISION OPERATIONS (2007) (noting that SEC Enforcement Division officials blamed the backlog of cases in part on a scarcity of time and administrative support); $c$. William Funk, Close Enough for Government Work?-Using Informal Procedures For Imposing Administrative Penalties, 24 SETON HALL L. REV. 1, 1-2 (1993) ("Traditionally, this judicial model was the primary means provided for assessing a civil penalty. The amount of government resources necessary to bring such a case, however, militates against using this tool except in "big' cases.").

52. See McNollgast, Administrative Procedures, supra note 37, at 262 ("[E]laborate procedures with stiff evidentiary burdens for decisions and numerous opportunities for seeking judicial review before the final policy decision is reached will benefit constituents that have considerable resources for representation," and "cumbersome procedures exemplify deck-stacking in favor of wellorganized, well-financed interests.").

53. More streamlined procedures have the opposite effect. Justice Sotomayor recently made a related point with regard to the impact of technology on the total level of enforcement. There, she observed that because GPS monitoring technology was "cheap in comparison to conventional surveillance techniques and, by design, proceeds surreptitiously, it evades the ordinary checks that constrain abusive law enforcement practices: "limited police resources and community hostility.", United States v. Jones, $132 \mathrm{~S}$. Ct. 945, 956 (2012) (Sotomayor, J., concurring) (quoting Illinois v. Lidster, 540 U.S. 419,426 (2004)).

54. It is true that the agency's authority to settle actions also allows it to bring more actions. But that takes nothing away from the thesis that summary judgment does so as well. Moreover, 
The text and history of the APA support this theory. Courts and scholars have devoted significant attention to the APA's distinction between "formal" and "informal" adjudications, ${ }^{55}$ but the APA also provides a second key distinction within formal adjudications. Section 556(d) provides (in part):

\begin{abstract}
A party [in a formal adjudication] is entitled to present his case or defense by oral or documentary evidence, to submit rebuttal evidence, and to conduct such cross-examination as may be required for a full and true disclosure of the facts. In rule making or determining claims for money or benefits or applications for initial licenses an agency may, when a party will not be prejudiced thereby, adopt procedures for the submission of all or part of the evidence in written form.
\end{abstract}

This section gives parties to formal APA adjudications ${ }^{57}$ an entitlement to live, in person hearings, ${ }^{58}$ but provides a limited exception for certain classes. ${ }^{59}$

there is a significant gulf between a settlement-which obviously depends on the consent of the defendant-and a summary judgment - which does not.

55. E.g., Seacoast Anti-Pollution League v. Costle, 572 F.2d 872, $875-78$ (1st Cir. 1978); City of W. Chi. v. NRC, 701 F.2d 632, 644-45 (7th Cir. 1983); Chem. Waste Mgmt., Inc. v. EPA, 873 F.2d 1477, 1480-83 (D.C. Cir. 1989); see also WILlIAM F. FUNK, SIDNEY A. SHAPIRO \& RuSSELL L. Weaver, Administrative Procedure And Practice: Problems and Cases 195-98 (4th Ed. 2010); A GuIde TO FEDERAL AGENCY ADJUDICATION § 3.01 (Michael Asimow, ed. 2003) [hereinafter ASIMOW, GUIDE] (elaborating on the distinction between formal and informal adjudication). Scholars have explored countless dimensions of the formal/informal divide. E.g., Jeffrey S. Lubbers, $A P A-$ Adjudication: Is the Quest for Uniformity Faltering, 10 ADMIN. L. J. AM. U. 65, 68 (1996); Paul R. Verkuil, Reflections Upon the Federal Administrative Judiciary, 39 U.C.L.A. L. REV. 1341 (1992); Gary J. Edles, An APA-Default Presumption for Administrative Hearings: Some Thoughts on "Ossifying" The Adjudication Process, 55 ADMIN. L. REV. 787 (2003); William S. Jordan III, Chevron and Hearing Rights: An Unintended Combination, 61 ADMIN. L. REV. 249, 273-74 (2009); Melissa M. Berry, Beyond Chevron's Domain: Agency Interpretations of Statutory Procedural Provisions, 30 SEATTLE U. L. REV. 541 (2007).

\title{
56. 5 U.S.C. \$ 556(d) (emphasis added).
}

57. Congress is free to avoid "formal adjudication" altogether. See supra note 55 (collecting sources on the formal/informal divide); see also Lubbers, supra note 55, at 70 (1996) (expressing anxiety that Congress was too frequently avoiding formal adjudication).

58. ASIMOW, GUIDE, supra note 55, at $\S 5.07$ ("The APA generally contemplates an oral hearing with 'live' presentation of evidence." (citing $\S 556(\mathrm{~d})$ )); 2 KENNETH CULP DAVIS, ADMINISTRATIVE LAW TREATISE 332-33 (2d ed. 1980) (stating that "a hearing on the record is the equivalent of a trial ... it is governed by trial procedure" and " $\$ 556$ clearly requires trial procedure"); Funk, supra note 51 , at 2 (noting that formal APA adjudication "mirrors the trial in the judicially imposed civil penalty").

59. Some courts have agreed with this reading. See, e.g., United States v. Fla. E. Coast Ry. Co., 410 U.S. 224, 241 (1973) ("[E]ven where the statute requires that the rulemaking procedure take place 'on the record after opportunity for an agency hearing,' thus triggering the applicability of $\S$ 556 , subsection (d) provides that the agency may proceed by the submission of all or part of the evidence in written form if a party will not be 'prejudiced thereby." (emphasis added)); Richardson v. Perales, 402 U.S. 389, 409 (1971) (finding, in a social security disability claim, that $\$ 556(\mathrm{~d})$ would authorize the agency to "adopt procedures for the submission of all or part of the evidence in written form" so long as the "party will not be prejudiced thereby"); NRDC v. EPA, 859 F.2d 156, 191 (D.C. Cir. 1988) (explaining that $§ 556$ (d) "explicitly exempts [initial licensing] from some elements of formal adjudication"); Gencom Inc. v. FCC, 832 F.2d 171, 174 n.2 (D.C. Cir. 1987) (describing $\S 556(d)$ as an "express exemption" from the "full panoply of trial-like hearing requirements embodied in $\$ 554$ of the APA" for "processing applications of initial licenses."); Seacost Anti-Pollution League v. Costle, 572 F.2d 872, 879 (1st Cir. 1978) ("[T]he Administrator [is] empowered to require that the new evidence be 
A straightforward reading of the last sentence of this provision ${ }^{60}$ (guided by the maxim of statutory interpretation, expressio unius ${ }^{61}$ ) is that, for formal adjudications not involving one of the excepted classes-"rule making or determining claims for money or benefits or applications for initial licenses"a party's "entitlement" to "present his case or defense by oral . . . evidence" and "conduct such cross-examination as may be required for a full and true disclosure of the facts" may not be abridged by the agency whether or not the party would be "prejudiced thereby." 62 The section therefore creates a distinction within formal adjudications: the right to in-person, live hearings may be dispensed with by the agency for licensing, rulemaking, and benefits cases, but not for enforcement or disciplinary ones.

Courts have largely overlooked this provision. While a few of the cases upholding administrative summary judgment fit into the exempted categories, they do so without analysis of the provision. ${ }^{63}$ And several cases uphold the use of summary judgment beyond the specifically exempted categories. ${ }^{64}$

This is not surprising. The distinction drawn by $\S 556(\mathrm{~d})$ is difficult to square with the Consensus Justification for administrative summary judgment that courts have uniformly adopted. ${ }^{65}$ On that view, Congress could not have

submitted in written form . . . . in cases of initial licensing."); Sierra Ass'n for Env't v. FERC, 744 F.2d 661, 664 (9th Cir. 1984) (relying on $\S 556(\mathrm{~d})$ in approving a "paper hearing" procedure for licensing application); see also MASHAW ET AL., supra note 1, at 425-26 ("[I]n connection with formal rulemaking or initial license applications, the agency may limit the parties to written presentations "when a party will not be prejudiced thereby.").

60. But see Richard Primus, The Limits of Enumeration, 124 YALE L.J. 576 (2014) (challenging the consensus that powers not enumerated in the constitution are reserved for the states).

61. Expressio unius est exclusio alterius stands for the proposition that the expression of one thing means the exclusion of the other.

62. Cf. ASIMOW, GUIDE, supra note 58, at $\$ 5.07$ ("The instances in which the agency can dispense with oral proceedings are formal rulemaking, determinations relating to claims for money or benefits, and applications for initial licenses.").

63. E.g., Weinberger v. Hynson, Wescott \& Dunning, Inc., 412 U.S. 609, 620-23 \& n. 19 (upholding summary judgment in a licensing case); United States v. Storer Broad. Co., 351 U.S. 192, 205 (1956) (upholding denial of hearing in a licensing case where respondents fail to "set forth reasons, sufficient if true" to justify relief, without discussing APA 556(d)); Puerto Rico Aqueduct \& Sewer Auth. v. EPA, 35 F.3d 600, (1st Cir. 1994) (broadly approving administrative summary judgment in a licensing case without citing or discussing $\$ 556(\mathrm{~d})$ ); see also FPC v. Texaco, Inc., 377 U.S. 33, 39, 45 (1964) (finding that the statutory hearing requirement did not preclude the FPC from denying hearings ("barring at the threshold") to those who plainly were not entitled to relief, but also explicitly holding that the denial of a hearing in this context was "not an "adjudication"" under APA); Richardson v. Perales, 402 U.S. 389, 410 (1971) (benefits); Seacost Anti-Pollution League at 872 (licensing/permitting); Citizens for Allegan Cty., Inc. v. FPC, 414 F.2d 1125 (D.C. Cir. 1969) (licensing); Robbins v. Cyprus Cumberland Coal Co., 146 F.3d 425, 428-29 (6th Cir. 1998) (benefits).

64. See infra Part III; e.g., Kornman v. SEC, 592 F.3d 173, 182 (D.C. Cir. 2010) (SEC); Gibson v. SEC, 561 F.3d 548 (6th Cir. 2009) (SEC); Brownson v. SEC, 66 Fed. App'x 687, 688 (9th Cir. 2003) (SEC); Crestview Parke Care Ctr. v. Thompson, 373 F.3d 743, 750 (6th Cir. 2004) (upholding rule "akin to the summary judgment standard contained in Federal Rule of Civil Procedure 56 " for HHS civil penalty proceedings); $c f$. Nat'l Indep. Coal Operators' Ass'n v. Kleppe, 423 U.S. 388, 399 (1976) (upholding the denial of a formal hearing before the assessment of a penalty, finding that a mine operator who failed to request a hearing (as required under that statutory regime) "in effect voluntarily defaulted and abandoned the right to a hearing").

65. See Puerto Rico Aqueduct, 35 F.3d at 605 (endorsing a version of the economic view, and dismissing the $\S 555$ (d) distinction as "sheer persiflage"). 
intended to require agencies to expend scarce enforcement resources on futile hearings. ${ }^{66}$ Thus, one court that adopted the Consensus Justification dismissed this distinction drawn by $\S 556(\mathrm{~d})$ as "sheer persiflage.,"67

But the distinction in $\S 556(\mathrm{~d})$ is no puzzle under the Unstacking the Deck view. The provision crystalizes Congress's intent to impose procedural costs on agencies for a certain set of proceedings (e.g., enforcement actions, disciplinary hearings), as a way to limit or channel enforcement programs. This purpose is independent of whether the hearing enhances the accuracy of the outcome. By requiring in person live hearings even where skipping such hearings would not "prejudice" the respondent, Congress was limiting or channeling enforcement. 68

The legislative history confirms this theory. The history of the APA's formal adjudication provisions shows that conservatives were attempting to use these procedures to control agency enforcement programs. ${ }^{69}$ As one New Deal Democrat explained, conservatives were attempting to use administrative procedure to limit the reach of New Deal agencies: "Legislation which they could not prevent they seek to frustrate ... . [The bill] would tie up every agency whose activities were not exempt from the provisions of the act."70 Conservatives could not "prevent" the substantive New Deal legislation, so they were attempting to "frustrate" it by imposing arduous procedures. Similarly, a leading history of the APA concludes that "both Roosevelt Democrats and conservatives recognized that a central purpose of the proponents of administrative reform was to constrain liberal New Deal agencies, especially the National Labor Relations Board and the Securities and Exchange Commission."71 Section 556(d) isolates enforcement hearings

66. Congress may have decided that the stakes of licensing and benefits cases were lower than for other adjudications, and so merited lower procedural costs. See supra note 28 (discussing the role of penalty magnitude in economic procedural analysis). But that alone cannot explain why Congress would have locked in formal procedures for all other cases, even where the hearings would be futile.

67. Puerto Rico Aqueduct, 35 F.3d at 605.

68. This shows only that Congress was not behaving irrationally; it may or may not have been behaving wisely. Cf. Walter Gellhom, The Administrative Procedure Act: The Beginnings, 72 VA. L. REV. 219, 232 (1986) ("Judicialization' of administration is unlikely to be advantageous in every setting, even where individual matters (as distinct from the shaping of future policies or the announcement of general rules) are the business of the day."); Edward Rubin, It's Time To Make the Administrative Procedure Act Administrative, 89 CORNELL L. REV. 95, 98 (2003) (criticizing the APA as imposing "excessive and counterproductive constraints on administrative agencies, while imposing too little control on agency action to the detriment of both fairness and efficiency in the administrative process").

69. See George B. Shepherd, Fierce Compromise: The Administrative Procedure Act Emerges from New Deal Politics, 90 Nw. U. L. REV. 1557 (1996); see also Martin Shapiro, APA: Past, Present, Future, 72 VA. L. REV. 447, 453 (1986); McNollGast, The Political Origins of the APA, supra note 47, at 213; Lubbers, supra note 55 , at 68 (describing formal adjudication procedure as the "centerpiece" of the APA).

70. 86 CONG. REC. 4654 (1940).

71. Shepherd, supra note 69 , at 1560 ; see also id. at 1606 (explaining that backers of more restrictive proposed legislation "intended the bill to suppress disfavored New Deal agencies such as the NLRB, the Labor Department's Wage and Hour Division, and the SEC"); id. at 1678 ("[T]he 
involving the imposition of sanctions, such as unfair labor practice cases before the NLRB and broker-dealer disciplinary hearings before the SEC-programs that attracted the particular ire of conservative opponents to the New Deal. ${ }^{72}$ Their particular hostility towards these agencies explains why Congress would want to preserve oral in person hearings-even "futile" ones-for these types of cases. $^{73}$

\section{The Two Theories Compared and Reconciled}

The Consensus Justification valorizes administrative summary judgment-it would be irrational to reject the procedure and insist on a "futile" hearing. ${ }^{74}$ By contrast, the Unstacking the Deck view is merely descriptive. Administrative summary judgment facilitates drift from the intent of the original legislative coalition, but that may or may not be a good thing for society. If the enacting Congress's decision to "stack" was welfare-enhancing, then "unstacking" would be unwise. But the opposite could just as easily be true. "Drift" is a political concept, not a utilitarian one. ${ }^{75}$

This apparent divergence between the scope of the two theories is actually just an artifact of the misplaced assumption built into the scholarly versions of the economic analysis that the underlying substantive law is welfare-

\footnotetext{
APA was a political compromise produced by a rugged political battle between conservatives and a liberal administration-a compromise of a battle over conservatives' attempts to hinder liberal administration programs by limiting the power of agencies to implement the programs."). Members of Congress expressed this sentiment in debates over precursors to the APA. E.g., 86 CONG. REC. 4655 (statement of Rep. Keller) (criticizing precursor to APA) ("That is the intention of this bill - not only to stop the NLRB but the Security and Exchange Commission ... . That is what it is intended to do. They admit that it will delay. They may as well admit the evident fact that if this bill should become law the delay will be so great as to tie the hands of all these commissions, and delay often means defeat .... It will stop the whole process of government along those lines."); but see JOEL SELIGMAN, THE TRANSFORMATION OF WALL STREET 153 (2003) (noting the SEC had "voluntarily" adopted key hearing procedures when the APA was still being considered by congress, and so "the act itself resulted in virtually no change in the Commission's procedures").
}

72. E.g., 86 Cong. Rec. 453 (1940) (statement of Rep. Cox) (floor debate on precursor to APA) (attacking the SEC as having "the same philosophy as most of these new agencies that have been set up in recent years, whose thinking is apparently rooted in doctrine that emanates from Russia"); 86 Cong. Rec. 4603 (statement of Rep. Hawkins) (floor debate on precursor to APA) (comparing SEC to "the tyrannies of the Gestapo of Germany, or the Russian OGPU ...").

73. See also Paul R. Verkuil, The Emerging Concept of Administrative Procedure, 78 COLUM. L. REV. 258, 294-301 (1978) (noting that "efficiency may be a less important value" for enforcement and disciplinary hearings than in other types of formal hearings); FUNK ET AL., supra note 55, at 206 ("The reason for the exception [for licensing] is the notion that in those types of cases there are not normally adverse parties involved in the adjudication; it is only a party submitting evidence in its support without any other party contesting it.").

74. See sources cited supra note 13-19 (collecting cases justifying summary judgment in cases where requiring a hearing would be "futile," and thus irrational)

75. Some early PPT scholars seemed to assume that drift was a normative concept, and that the original enacting Congress is the only politically legitimate source of law, and so any deviation therefrom was undesirable. Later scholars backed away from this view. See discussion infra text accompanying notes 224-235. 
enhancing. ${ }^{76}$ More (accurate) adjudications are better (setting aside procedural costs) only if this underlying assumption holds. Though a useful way to present an elegant theory of procedure, the assumption is not realistic. Some substantive legal rules are welfare-diminishing. Enforcement of such "bad laws" harms social welfare-and more enforcement is even worse. ${ }^{77} \mathrm{~A}$ procedure that obstructs the cost-effective, accurate enforcement of such a law would be welfare-enhancing. Further, some laws are welfare-enhancing up to a certain level of enforcement, but beyond that, welfare-diminishing. A procedural regime that led the agency to prioritize "good" prosecutions and deprioritize "bad" ones (or vice versa) could be welfare-maximizing, even without maximizing the number of accurate adjudications. ${ }^{78}$

Once the assumption about the quality of the underlying law is relaxed, the merits of administrative summary judgment are no longer solely dependent on a simple calculation of the tradeoff between accuracy and costs, but rather depend on the underlying program itself. As theories, Consensus Justification and Unstacking the Deck thus are not as far apart as it seemed. Unfortunately, when courts then draw on economic theory of procedure, they too often overlook this assumption that underlies the scholarly analysis.

76. See Louis Kaplow \& Steven Shavell, Fairness Versus Welfare, 114 HARV. L. REV. $961,1164-65$ (2001) (identifying that "the relationship between legal procedure and the substantive law that provides the underlying basis for lawsuits" is "central," because from that perspective procedure is simply "the means by which substantive rules are ultimately enforced," and then proceeding to provide a trans-substantive analysis of legal procedure); cf. Klerman, supra note 22, at 354-55 (acknowledging that the economic analysis of error costs is awkwardly applied to areas like anti-discrimination or privacy, where "economic analysis is less clear or more controversial," but insisting that "to the extent that discrimination and invasion of privacy can be conceived of as harms and those harms can be monetized or expressed in a social welfare function, the economic analysis of procedure in terms of direct costs and error costs is applicable").

77. Compare fig.1 and fig.2.

78. See fig.3. 
Figure 1: Good Law

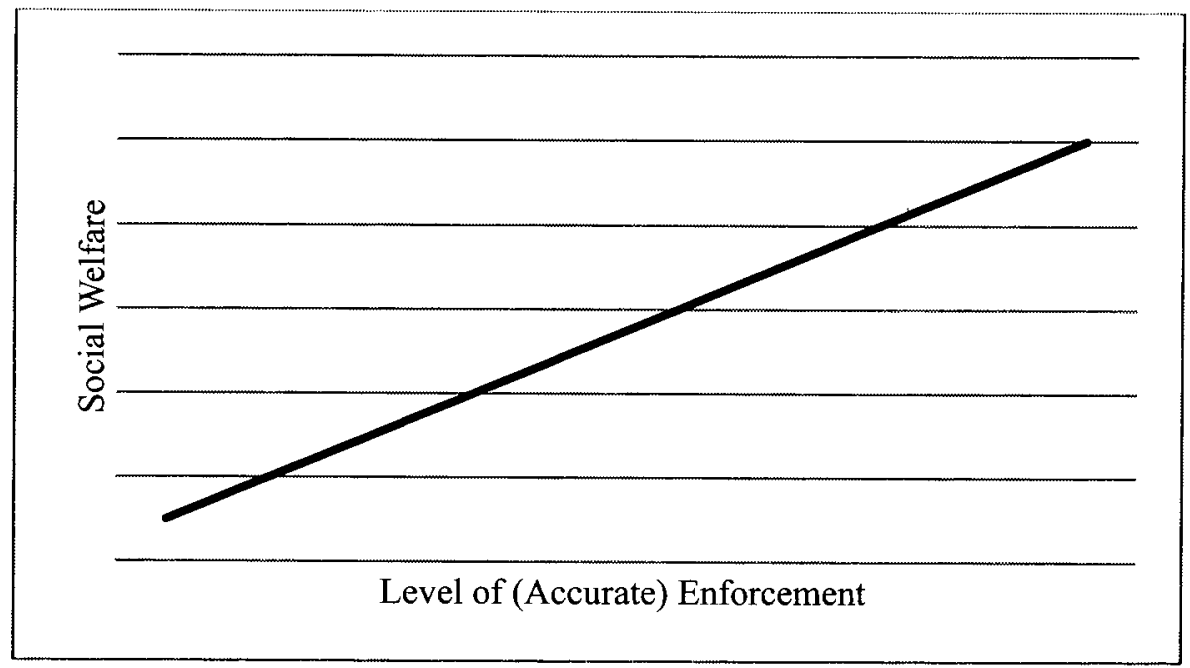

Figure 2: Bad Law

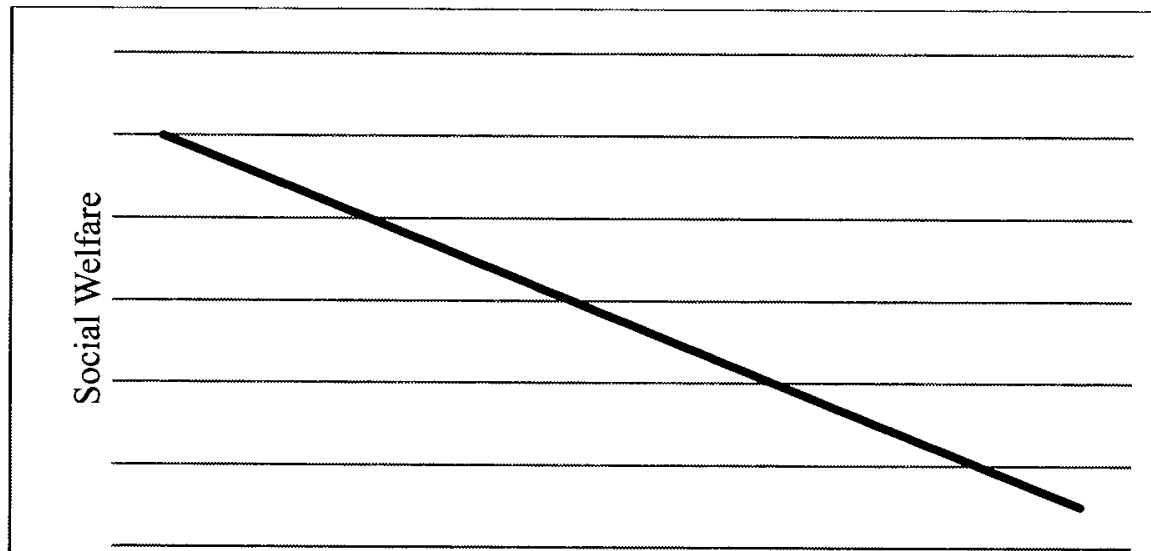

Level of (Accurate) Enforcement 
Figure 3: Mixed Law

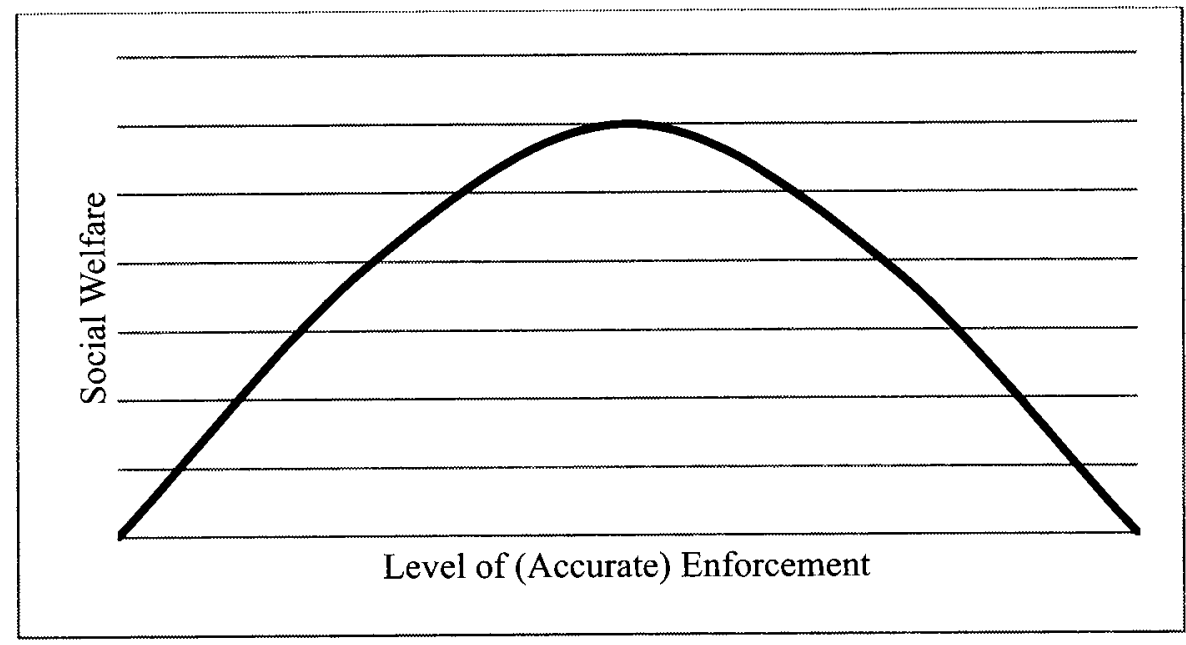

II. Indicia of Unstacking

The broad acceptance of administrative summary judgment rests on a flawed intellectual foundation - one that fails entirely to account for any impact on programmatic enforcement decisions, for any values behind Congress's decision to require full hearings other than a tradeoff between accuracy and cost, for the structural incentives that may skew administrative prosecutors' decisions regarding what hearings are and are not required, or for the distinctions between the civil and administrative applications of summary judgment. The alternative theory, Unstacking the Deck, presents administrative summary judgment as a mechanism to undo the procedural controls Congress imposed on an agency enforcement program and as a battleground for competing political agendas. It expects that agency prosecutors will wield this tool in pursuit of political and programmatic goals.

Testing these rival theories requires some way to discern whether an agency is relying on summary judgment to steer its enforcement program away from an enacting Congress's intentions, and not just making individualized determinations about summary judgment on a case-by-case basis. It also requires determining whether agency prosecutors are conducting the cost/accuracy calculation correctly, or are putting a thumb on the scale in favor of more permissive summary judgment rules.

Neither of these claims is easily subject to direct testing. ${ }^{79}$ Nevertheless, it is possible to construct a rough proxy to test these two theories. ${ }^{80}$ This Part

79. Some have said the same about McNollgast's theory more generally. See Glen $\mathrm{O}$. Robinson, Commentary on "Administrative Arrangements and the Political Control of Agencies": 
presents four "indicia of unstacking" ("I-1," "I-2," etc.). To the extent an agency's behavior conforms to these indicia, that would tend to indicate its summary judgment program is serving as an instrument of programmatic "drift" from an original enacting legislative coalition, and not merely of neutral technocratic efficiency on a case-by-case basis. The factors are not exhaustive, and also overlap to some extent.

I-1: Drifting agencies will develop summary judgment programs in response to calls for increased or refocused enforcement.

Formal adjudicatory procedures limit or channel agency enforcement. Summary judgment liberates the agency from those constraints. It allows agency enforcers and adjudicators to do more with less, to bring and resolve more actions without expending more resources. It also allows agencies to pursue a different mix of actions; summary judgment may facilitate the enforcement of certain rules that may not have been otherwise "worth" the costs to the agency of enforcing. An agency seeking to cover more ground with its enforcement program may find in summary judgment a useful tool.

One proxy for whether an administrative summary judgment is having a programmatic effect on agency enforcement is whether the agency's use of the procedure is a response to political calls for generally expanded enforcement. Such calls could come from members of Congress, from within the executive branch, or elsewhere. They could be the result of a broader political movement, in response to some crisis or scandal, as a product of electoral politics, as a reaction to (actual or perceived) agency failure, or from some other source. ${ }^{81}$ Summary judgment may be an appealing response to these calls for a steppedup enforcement presence without expending any extra resources. ${ }^{82}$

I-2: Drifting agencies will use summary judgment to boost enforcement statistics.

Political Uses of Structure and Process, 75 VA. L. REV. 483, 484 (1989) (criticizing McNollgast's model as "too general in its description of processes and structure to permit useful generalizations about how they can be used to 'stack the deck' in favor of specific political interests"); see also Bressman, supra note 25 , at 1770 n. 127 .

80. See Jonathan R. Macey, Administrative Agency Obsolescence and Interest Group Formation: A Case Study of the SEC at Sixty, 15 CARDOZO L. REV, 909, 918 (1994) (noting "the difficulty" of determining agency obsolescence, but developing general "indicia of agency obsolescence" and then tracing these indicia through a particular agency-the SEC).

81. I am not thinking, here, of (for instance) the detailed and nuanced reports studies and articles steadily issued by academics, industry, and others recommending certain priorities for enforcers. Rather, I am thinking of the undifferentiated demands by non-experts, shaped primarily by political or public relations considerations (rather than expert ones) that the enforcers simply do more or do something concrete that shows they are "effective." This is likely a familiar driver of enforcement programs for all students of enforcement, but perhaps especially to those who study securities. See, e.g., sources cited in note 146 .

82. Administrative enforcement programs are shaped by a rich and complex set of factors. In a recent normative paper, Professor Lemos distills these inputs down to a spectrum ranging from "independence" and "accountability." The inputs I discuss here fall on the "accountability" side of the spectrum. Unlike Lemos's discussion, however, this one is neither intended to criticize nor endorse the proposition that agency enforcement should be shaped by current as opposed to original legislative intent. See Lemos, Accountability and Independence in Public Enforcement, supra note 32. 
Relatedly, a drifting agency may take advantage of administrative summary judgment to promote enforcement numbers that please their legislative overseers. Agencies are required to provide regular performance reports to Congress. ${ }^{83} \mathrm{~A}$ drifting agency may recalibrate its enforcement program to bring more actions amenable to administrative summary judgment in order to boost its statistics and please Congress.

Unfortunately, a drifting agency may pursue this goal whether or not this numerical goal is a meaningful measure of the quality of enforcement. ${ }^{84}$ As "behavioral economics" has become a leading justification for government intervention, ${ }^{85}$ scholars have drawn attention to the fact that the same biases that skew the decision making of ordinary individuals also affect government officials. The result, and the focus of literature on behavioral public choice, is that "government policies often institutionalize rather than overcome behavioral anomalies." 86 Quantitative metrics like the "total number of cases filed," the "win/loss record," or "total \$ recovered" have been known to pose a risk of unjustified certainty. ${ }^{87}$ They may lead to over-valuing that which can be

83. E.g., 15 U.S.C. $\$ 78 \mathrm{w}(\mathrm{b})(1)$ (requiring the SEC, Federal Reserve, Comptroller of the Currency, and FDIC to report annually to Congress "whatever ... data" that the agency considers relevant); Government Performance and Results Act of 1993, § 2(a), (b), Pub. L. No. 103-62 (requiring agencies to measure performance results and report the results annually); see also Urska Velikonja, Reporting Agency Performance: Behind the SEC's Enforcement Statistics, 101 CORNELL L. REV. 901, 912-15 (2016).

84. See Velikonja, Reporting Agency Performance, supra note 83, at 912 ("You get what you measure. And what is measured is managed and rewarded, often to the exclusion of qualities that cannot be measured.").

85. Psychologists have demonstrated that individuals suffer from systemic cognitive biases, leading them to fail to act rationally. For a review, see DANIEL KAHNEMAN, THINKING FAST AND SLOW (2011). These findings have led some to promote government interventions to mitigate these biases. E.g., RICHARD H. THALER \& CASS R. SUNSTEIN, NudGe: ImProving DECISIONS ABouT HEALTH, WEALTH, AND HAPPINESS (2008). In particular, scholars have justified an expansive role for the SEC with reference to the cognitive limitations of investors. E.g., LANGEVOORT, SELLING HOPE, SELLING RISK, supra note 5); Lawrence A. Cunningham, Behavioral Finance and Investor Governance, 59 WASH. \& LEE L. REV. 767 (2002); Donald Langevoort, Selling Hope, Selling Risk: Some Lessons for Law from Behavioral Economics about Stockbrokers and Sophisticated Customers, 84 CALIF. L. REV. 627 (1996); Donald Langevoort, Taming the Animal Spirits of the Stock Markets: A Behavioral Approach to Securities Regulation, 97 Nw. U. L. REV. 135, 153 (2002); Robert Prentice, The Inevitability of a Strong SEC, 91 CORNELL L. REV. 775, 797-98 (2006); Robert Prentice, Whither Securities Regulation? Some Behavioral Observations Regarding Proposals for its Future, 51 DUKE L.J. 1397 (2002).

86. W. Kip Viscusi \& Ted Gayer, Behavioral Public Choice: The Behavioral Paradox of Government Policy 6 (Mercatus Working Paper, Mar. 2015); see also Stephen J. Choi \& A.C. Pritchard, The SEC's Shift to Administrative Proceedings: An Empirical Assessment, 34 YALE J. ON REG. 1, 5 (2017) ("[I]f everyone suffers from cognitive defects, doesn't that also include the commissioners and staff of the SEC?"). For an application of behavioral psychology findings to different category of government employees (judges) see Alexander I. Platt, Debiasing Statutory Interpretation, 39 OHIO N.U. L. REV. 275 (2012).

87. E.g., MARK TWAIN, Chapters FROM MY AUTOBIOGRAPHY (1906) ("“Figures often beguile me,' he wrote, 'particularly when I have the arranging of them myself; in which case the remark attributed to Disraeli would often apply with justice and force: "There are three kinds of lies: lies, damned lies, and statistics." ). Dan Kahan and colleagues have shown that even mathematically literate people accord inappropriate weight to evidence that seem to confirm certain identity-constituting political beliefs. Dan M. Kahan et al., Motivated Numeracy and Enlightened Self-Government, (Yale Law Sch. Public Law Working Paper No. 317, 2013). 
readily measured (and undervaluing that which cannot be) —an error sometimes referred to as the "drunkard's fallacy" or the "streetlight effect," after the joke about the drunk searching for a lost object under a streetlight because "that's where the light is." ${ }^{88}$ Summary judgment may facilitate an agency's ability to produce the "right" numbers.

I-3: Drifting agencies will use summary judgment to bring more minor actions and target weaker defendants.

Drifting agencies want to avoid triggering backlash that will slow down its drift. Thus, for instance, they will strive to avoid triggering "fire alarms" and judicial review. Politically weak defendants can't pull fire alarms. Economically weak defendants can't afford to pursue effective judicial review.

An enforcement agency with prosecutorial discretion must prioritize its enforcement resources. In a regime without summary judgment, enforcement is expensive: there are substantial fixed costs for each litigated proceeding. Regardless of how easy a case is, the respondent will be entitled to an oral hearing before an ALJ. The agency will be disinclined to waste scarce resources on low-level cases. Even if many of them will settle, the few that do not will prove not worth the procedural costs.

Summary judgment allows the agency to quickly dispose of the easiest cases without the cost of a hearing even where the defendant refuses to settle. By lowering the procedural costs of a given action, summary judgment essentially empowers the agency to process cases, rather than adjudicate them-functioning more like a DMV than a court. ${ }^{90}$ Summary judgment makes enforcement cheaper, and thereby makes easy but trivial cases much more attractive.

A drifting agency will incorporate this change in costs into its enforcement program. It will bring more actions that are less significant and target weaker defendants.

I-4: Administrative prosecutors at drifting agencies will "play for the rules" to develop broad summary judgment programs through case-by-case adjudication, not rulemaking.

\section{Here's the joke:}

Late at night, a police officer finds a drunk man crawling around on his hands and knees under a streetlight. The drunk man tells the officer he's looking for his wallet. When the officer asks if he's sure this is where he dropped the wallet, the man replies that he thinks he more likely dropped it across the street. Then why are you looking over here? the befuddled officer asks. Because the light's better here, explains the drunk man.

David H. Freedman, Why Scientific Studies are So Often Wrong: The Streetlight Effect, DISCOVER MAG. (Dec. 2010).

89. For a comprehensive discussion of manipulation of agency reporting data see Velikonja, Reporting Agency Performance, supra note 83; see also Barkow, Overseeing Agency Enforcement, supra note 32 , at 141 .

90. See Jerry MASHAW, BUREAUCratic JuSTICE 25 (1983). 
According to the Consensus Justification, agency prosecutors are tasked with determining whether a hearing is required in individual cases based on whether the hearing would do anything to enhance the accuracy of the outcome. But, as discussed above, these prosecutors have both the incentive and the ability (because of their repeat player advantage inside administrative adjudication) to "play for the rules"- that is, to obtain broader, more permissive rules governing the use of summary judgment. And ALJs may not be in a position to resist. ${ }^{9}$

In many agencies, adjudicatory procedural rules are ordinarily enacted through APA notice and comment. ${ }^{92}$ But, for a drifting agency, advancing permissive summary judgment rules via case-by-case adjudication may be preferable. Rulemaking is the paradigm case for triggering the procedural controls that a drifting agency is wise to avoid. ${ }^{93}$

Thus, agency prosecutors in a drifting agency will leverage their procedural advantage inside case-by-case adjudication to develop favorable rules governing summary judgment, rather than go through notice and comment rulemaking.

These four indicia provide a baseline to challenge the explanatory power of the Consensus Justification for administrative summary judgment, and to explore the rival theory advanced here, Unstacking the Deck. The next Part applies these indicia to a case study.

\section{Case Study: SEC Summary Disposition}

The SEC's Division of Enforcement enforces the securities laws in two fora: civil proceedings in federal court and internal administrative proceedings, ${ }^{94}$ a species of APA formal adjudication. ${ }^{95}$ Administrative proceedings are presided over by ALJs and governed by the SEC's "Rules of Practice." 96

Much attention has lately focused on the Enforcement Division's shift away from district court actions towards the Commission's own administrative

91. See supra note 205 (discussing ALJ bias).

92. E.g., Amendments to the Commission's Rules of Practice 80 Fed. Reg. 60,091 (Oct. 5, 2015) (to be codified at 17 C.F.R. 201).

93. E.g., McNollgast, Administrative Procedures, supra note 37, at 257-59.

94. The Division also makes referrals to the Department of Justice for criminal prosecutions. 17 C.F.R. $\S 202.5(\mathrm{~b})$; see also 2 HAROLD S. BlOOMENTHAL \& SAMUEL WolfF, SECURITIES LAW HANDBOOK $§ 26: 56$ (2014 ed.).

95. See Steadman v. SEC, 450 U.S. 91,96 n.13 (1981); see also 15 U.S.C. $\$ \$ 77 \mathrm{~h}-$ $1(\mathrm{~g})(1), 78 \mathrm{o}(\mathrm{b})(4), 78 \mathrm{u}-2(\mathrm{a})(1) \&(2), 80 \mathrm{a}-9(\mathrm{~d}), 80 \mathrm{~b}-3$ (f) (requiring a hearing "on the record").

96. 17 C.F.R. $\$ 201.100$ et seq. "Respondents" (individuals charged in APs) can appeal an adverse decision by an ALJ to the Commission itself, and then can appeal that decision to a U.S. Court of Appeals. For a recent overview of APs, see Stavros Gadinis, The SEC and the Financial Industry, 67 BUS. L. 679 (2012). 
forum. ${ }^{97}$ After the 2010 Dodd-Frank Act expanded the penalties available inside these administrative proceedings, ${ }^{98}$ the SEC began ramping up its use of these internal proceedings where it enjoys substantial procedural advantages and its success rate has been higher. ${ }^{99}$ This shift has been greeted with outrage among key stakeholders and opinion-leaders, ${ }^{100}$ culminating in a wave of broad constitutional challenges $^{101}$ and calls to overhaul the procedures governing these proceedings. ${ }^{102}$

Both lines of attack - constitutional challenge and procedural reformcall for careful attention to administrative proceedings as they operate in practice. ${ }^{103}$ Several studies have looked at the Enforcement Division's choice of forum (administrative proceedings versus district courts) and its comparative success rate in each. ${ }^{104}$ Others have looked at the nature of actions pursued, characteristics of respondents, and the size of penalties. ${ }^{105}$ Still others have

97. See Platt, supra note 4.

98. Dodd-Frank Wall Street Reform and Consumer Protection Act $\S \S 925,929 \mathrm{P}$, Pub. L. No. 111-203 (2010); see also Platt, supra note 4, at 7 .

99. See, e.g., Platt, supra note 4, at 8-11; see also Choi \& Pritchard, supra note 86; David T. Zaring, Enforcement Discretion at the SEC, 94 TEXAS L. REV. 1155 (2016).

100. E.g., Jed S. Rakoff, Speech Before the Practicing Law Institute: Is the SEC Becoming a Law Unto Itself? (Nov. 5, 2014); see also SEC v. Citigroup Global Markets Inc., $34 \mathrm{~F}$. Supp. 3d 379, 380 n.8 (S.D.N.Y. 2014) (Rakoff, J.).

101. E.g., Lucia v. SEC, No. 15-1345, 832 F.3d 277 (D.C. Cir. 2016); Jarkesy v. SEC, 803 F.3d 9 (D.C. Cir. 2015) aff'g 48 F. Supp. 3d 32 (D.D.C. 2014); Chau v. SEC, 72 F. Supp. 3d 417 (S.D.N.Y. 2014); Stilwell v. SEC, 14-cv-7931 (S.D.N.Y. filed Oct. 1, 2014); Peixoto v. SEC, 14-cv8364 (S.D.N.Y. filed Oct. 20, 2014); Bebo v. SEC, 799 F.3d 765 (7th Cir. 2015), aff'g 2015 WL 905349 (E.D. Wis. Mar. 3, 2015); Decision \& Order, Duka v. SEC, 15-cv-357 (S.D.N.Y. Aug. 3, 2015), ECF No. 57; Hill v. SEC, Nos. 15012831, 15-13738 (11th Cir. Jun. 17, 2016), rev'g Order, Gray Fin. Grp. v. SEC, $15-\mathrm{cv}-492$ (N.D. Ga. Aug. 4, 2015), ECF No. 56 and rev'g 114 F. Supp 3d 1297 (N.D. Ga. 2015); Tilton v. SEC, 824 F.3d 276 (2d Cir. 2016), aff'g 15-cv-2472, 2015 WL 4006165 (S.D.N.Y. June 30, 2015); Order, Spring Hill Capital Partners, LLC v. SEC, 15-cv-4542 (S.D.N.Y. June 26, 2015), ECF No. 23; Order, Timbervest v. SEC, 15-cv-2106 (N.D. Ga. Aug. 4, 2015), ECF No. 25.

102. The SEC very recently enacted some reforms to dispositive motions, the timing of proceedings, depositions, hearsay and some other areas. See Amendments to the Commission's Rules of Practice, Final Rule SEC Release No. 34-78319 (July 13, 2016), https:/www.sec.gov/rules/final/2016/34-78319.pdf. Time will tell if these changes quell the mounting insurrection. See Platt, supra note 4, at 39-40 (arguing the proposed rules were inadequate).

103. In a recently denied Appointments Clause challenge to the SEC's ALJ system, an amicus brief filed by Paul Clement cites this Article's findings (pre-reported in an earlier-published Article) regarding the low rate of success for respondents in summary disposition as evidence that the SEC Administrative Proceedings' procedural system is unfair. Brief of Amici Curiae Ironridge Global IV, Ltd. at 12, 14, Lucia v. SEC, No. 15-1345 (D.C. Cir. Feb. 29, 2016), https://assets. documentcloud.org/documents/3009036/Clement-Brief-SEC-ALJ.pdf.

104. E.g., Choi \& Pritchard, supra note 86; Jean Eaglesham, SEC Wins With In-House Judges, WaLL ST. J. (May 6, 2015); Jean Eaglesham, SEC Is Steering More Trials to Judges It Appoints, WALL ST. J. (Oct. 21, 2014); see generally Platt, supra note 4. For a criticism of the Wall Street Journal studies see Velikonja, Reporting Agency Performance, supra note 83, at 976 nn.414-16.

105. See, e.g., Gadinis, supra note 96; Cox \& Thomas, supra note 51; Sonia A. Steinway, Comment, SEC "Monetary Penalties Speak Very Loudly, "But What Do They Say? A Critical Analysis of the SEC's New Enforcement Approach, 124 YALE L.J. 209, 210 (2014); see also Urksa Velikonja, Politics in Securities Enforcement, 50 GA. L. REV. 17, n.22 (2015) (collecting recent studies of SEC enforcement). 
looked at the agency's changing settlement practice. ${ }^{106}$ But to date, little attention has been paid to the details of the procedural mechanics inside litigated administrative proceedings.

A close look yields a surprising result: over the last decade, SEC administrative proceedings have quietly become comprised of two separate procedural regimes, operating side by side. Under the first, respondents receive an oral hearing, including the right to confront the adjudicator in person, to cross-examine government witnesses, and to take the stand to plead innocence or beg for forgiveness. Under the second, they get none of the above. This bifurcation is the product of the Enforcement Division's innovative use of the "Motion for Summary Disposition,"107 a form of administrative summary judgment. To date, the Division's expansive reliance on summary disposition has been largely overlooked even by the most eager critics of the agency's enforcement practice. ${ }^{108}$

This Part examines SEC summary disposition as a case study to test the Unstacking the Deck theory. Section A documents the agency's development of a summary disposition program using an original dataset comprised of every successful use of the motion from 1996 through 2014. Section B reviews this development through the lens of the Consensus Justification and shows how courts have relied on this framework in upholding the practice. Section $\mathrm{C}$ uses the Unstacking the Deck theory to offer a more complete account for the rise of summary disposition. ${ }^{109}$

106. Urska Velikonja, Securities Settlements in the Shadows, 126 YALE L.J. FORUM
107. See 17 C.F.R. $\$ 201.250$.
108.

108. There are exceptions. Some have recognized the trend of SEC summary
Lee Luke T. Cadigan, Litigating an SEC Administrative Proceeding, 58 BOSTON BAR J. 8, disposition. See Luke T. Cadigan, Litigating an SEC Administrative Proceeding, 58 BOSTON BAR J. 8,
12 (Jan. 7, 2014) (noting in passing that "summary disposition is usually reserved only for follow-on actions ... or those seeking to revoke registration of securities"); 70 Fed. Reg. 72,566, 72,567 (2005) (acknowledging that summary disposition motions "are often made in cases where a respondent has been criminally convicted"); 6 THOMAS HAZEN, LAW SEC. REG. $\$ 16.11$ ("[S]anctions can be imposed without a hearing where there is no factual dispute, as is the case for example with respect to a statutory disqualification based on a criminal conviction."); see also Kornman, 592 F.3d at 182. More have noted that summary disposition is generally unavailable for respondents. See Cadigan, supra, at 12 ("As a practical matter, there are also no dispositive motions prior to the hearing."); William F. Johnson \& Amelia R. Medina, SEC's Administrative Enforcement Intensifies Fairness Debate, 252 N.Y. L.J. (Nov. 6, 2014), http://www.newyorklawjournal.com/id=1202675574765/SECs-AdministrativeEnforcementIntensifies-Fairness-Debate?slreturn=20150826104029 ("[N]o dispositive motion practice prior to the hearing, with rare exceptions."); see also Compl. ๆ 37, Peixoto; Compl. ๆ 29, Gray Fin. Grp.; Compl. I 23, Duka. But see Order on Mot. for Partial Summary Disposition, OX Trading, LLC, 314853, (Sept. 5, 2012) (Murray, C.J.) (quoting SEC Rules of Practice, Exchange Act Release No. 3435833, 60 Fed. Reg. 32,738, 32,767-68 (June 23, 1995)) ("In 1995, when the Commission began to allow motions for summary disposition, ... it expected that summary disposition would be 'sought or granted ... comparatively rare[ly].' However, much has changed in the last almost twenty years, and successful motions for summary disposition are no longer rare.").

109. This study is limited to a single agency. In a separate paper, I look at the summary judgment practices of other enforcement agencies, including FTC and CFTC. This paper is also limited to successful uses of summary disposition, rather than all uses of the motion. The reason is purely practical: grants of summary disposition are more reliably published on the SEC website and Westlaw than the motions themselves or denials. 


\section{A. The Rise of SEC Summary Disposition}

Since 1995, ${ }^{110}$ the SEC's Rules of Practice have authorized "the respondent or the interested division" in an AP to "make a motion for summary disposition of any or all allegations" before the hearing "with leave of the hearing officer." 111 An ALJ reviewing such a motion must take as true "[t]he facts of the pleadings of the party against whom the motion is made.,"112

In the first nineteen years after its introduction in 1995, motions for Summary Disposition grew into an increasingly important feature of the SEC's enforcement program. ${ }^{113}$ By the mid 2000s, summary dispositions accounted for a significant portion of the agency's litigated cases. This has essentially bifurcated administrative proceedings: on the first track, respondents are entitled to a live hearing, at which they can take the stand and subject the government's witnesses to cross-examination; on the second, they get none of the above.

Figure 4: Rise of the Summary Disposition Grants for SEC

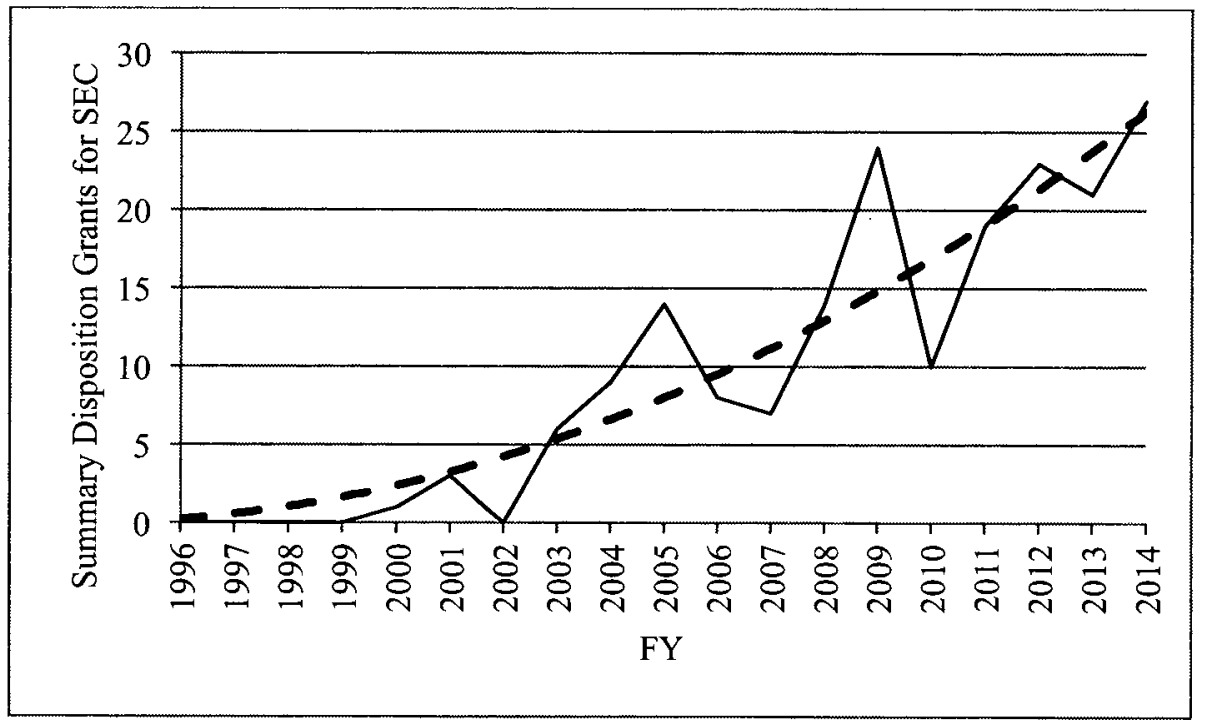

110. See 1995 Fed. Reg. SEC Rules; see also Puerto Rico Aqueduct \& Sewer Auth. v. EPA, 35 F.3d 600, 606 n.5 (1st Cir. 1994) (identifying the SEC as an outlier among agencies for not providing for administrative summary judgment in 1994).
111. 17 C.F.R. $\$ 201.250$ (a)
112. Id.
113. See figs. $4,5 \& 6$. 
Figure 5: Summary Dispositions in Favor of the SEC as a Percentage of all Initial Decisions ${ }^{114}$

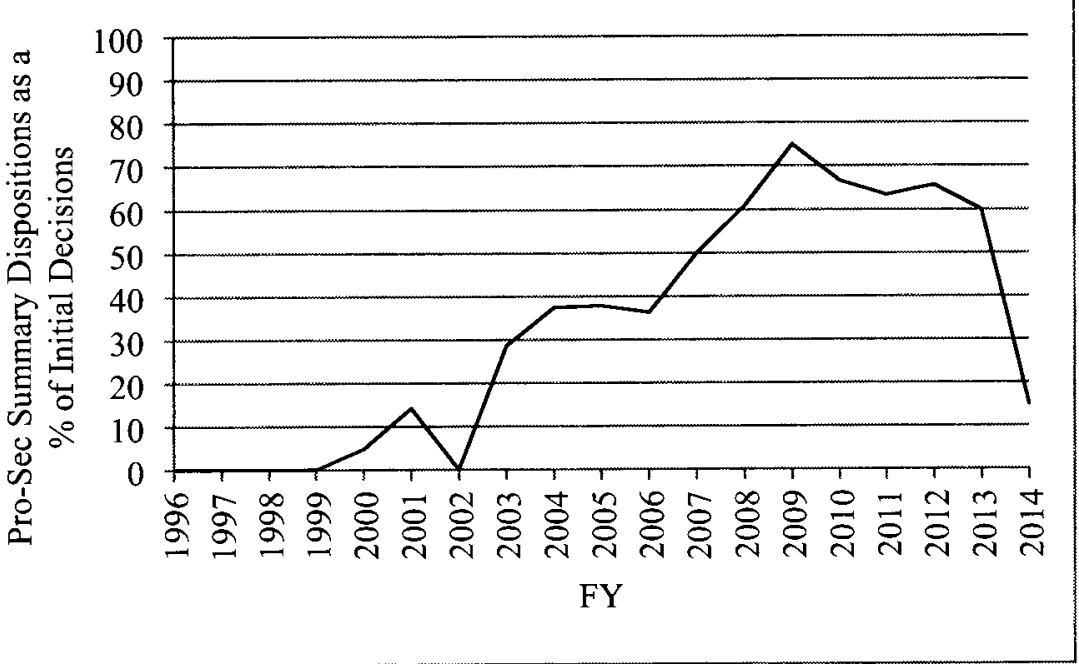

Figure 6: Summary Dispositions in Favor of the SEC as a Percentage of all Administrative Proceedings Initiated

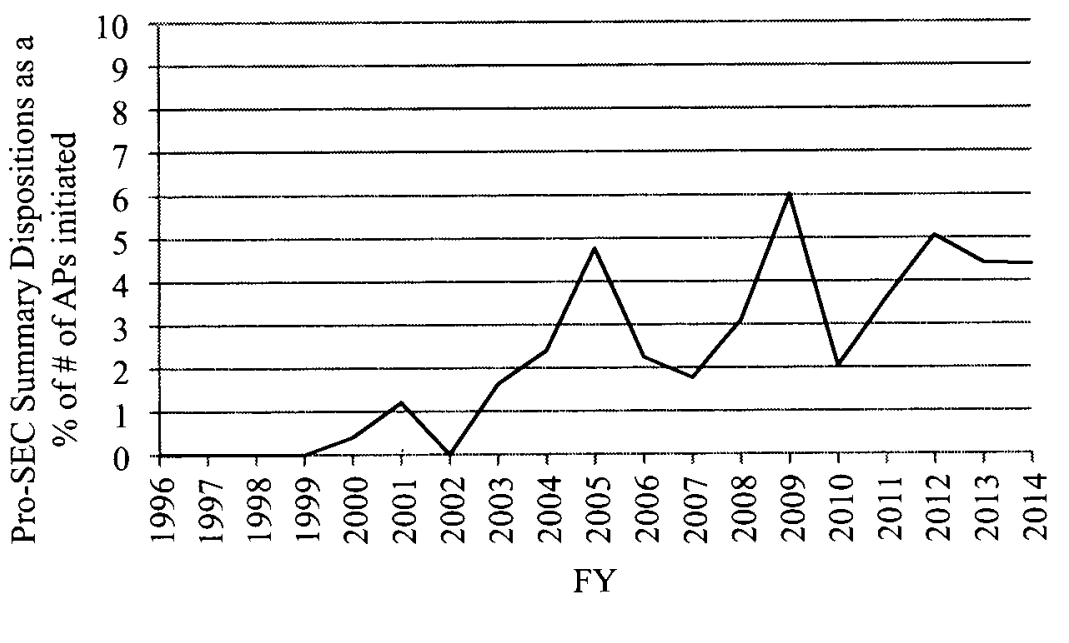

114. Although not all summary disposition grants are contained in Initial Decisions (some are contained in "Orders" or "Rulings" not titled "Initial Decisions"), Initial Decisions provide a useful comparator for the rate of pro-SEC Summary Dispositions over this period. The final year of data is skewed by the fact that the SEC brought more primary actions in the administrative forum rather than in federal court. Since summary disposition is most frequently used in follow-ons, the percentage resolved on summary disposition in this year shrinks dramatically. 
Successful uses of the motion are overwhelmingly made by the Enforcement Division. ${ }^{115}$ Respondents have won outright dismissal through pre-hearing summary disposition on a mere five occasions, ${ }^{116}$ one of which was promptly reversed by the Commission. ${ }^{117}$ By contrast, the Enforcement Division has won summary disposition nearly 200 times. $^{118}$

Because cases resolved on summary disposition take up much less timefor the Enforcement Division, the ALJ, and the respondent-they serve as a "force multiplier," enabling the agency to pursue more cases and resolve them more quickly, by dispensing with the costly procedural rights of formal adjudication. $^{119}$

Table 1: Summary Disposition Grants, FY 1996-2014

\begin{tabular}{|c|c|}
\hline & Summary Disposition Grants: 1996-2014 \\
\hline Respondents & 5 \\
\hline Enforcement Division & 186 \\
\hline Total & 191 \\
\hline
\end{tabular}

The penalties that can be imposed on summary disposition are not restricted. Two thirds of summary dispositions granted for the agency have involved some sort of bar. ${ }^{120}$ This is notable, given that as discussed above, the current controversy around administrative proceedings was triggered by the legislative expansion of the SEC's penalty authority in that forum, including the power to bar individuals from the entire securities industry (so-called "collateral bar" authority). ${ }^{121}$

115. See tbl.1.

116. See In re Ernst \& Young, LLP, 3-10786 (July 2, 2002) (Ruling); In re Information Architects Corp., 3-11822, No. 299 (Oct. 25, 2005) (Initial Decision); In re Salvatore F. Sodano, 3-12596, No. 333 (Aug. 20, 2007) (Initial Decision); In re Diatect Int'l Corp., 3-12843, 312843, No. 344 (Jan. 30, 2008) (Initial Decision); In re Vokonics, Inc., 3-13918, No. 405 (Oct. 22, 2010).

117. In re Salvatore F. Sodano, 3-12596, Rel. No. 59141 (Dec. 22, 2008) (Comm'n).

118. See tbl.1.

119. Another driver of the SEC's use of summary disposition is the rate at which defendants contest the charges brought against them. Where defendants are willing to settle cases, summary disposition is not needed. Thus, as the rate of contested cases increases, the rate of summary disposition would also increase.

120. See tbl.2.

121. Dodd-Frank, $\S 925,929 \mathrm{P}$; see also Chad Howell, Back to the Future: Applying the Collateral Bars of Section 925 of the Dodd-Frank Act to Previous Bad Acts, 7 J. BUS. \& TECH. L. 285,288 (2012) ("Essentially, the Commission is now authorized to put an individual completely out of the regulated securities business, even out of areas that had nothing to do with the violation of the securities law for which the individual was charged."); Platt, supra note 4. 
Table 2: Penalties Imposed on Summary Dispositions, FY 1996-2014

\begin{tabular}{|c|l|}
\hline Granted Motions for Division & 186 \\
\hline Bar & 125 \\
\hline${\text { Accountant } \text { Bar }^{122}}^{123}$ & 3 \\
\hline${\text { Attorney } \text { Bar }^{124}}^{124}$ & 3 \\
\hline Collateral Bar $^{125}$ & 45 \\
\hline BD Bar $^{126}$ & 45 \\
\hline IA Bar $^{127}$ & 33 \\
\hline Disgorgement $^{128}$ & 7 \\
\hline Civil Penalties $^{128}$ Cease and Desist $^{129}$ & 4 \\
\hline${\text { Revoked Registration } \text { Only }^{130}}$ & 9 \\
\hline
\end{tabular}

Though the rule is not formally confined to any particular category of cases, ${ }^{131}$ the Division has used summary disposition predominantly in two categories of cases: follow-on proceedings and delinquent filings. ${ }^{132}$

Follow-on Proceedings. Securities-related violations can be pursued as criminal prosecutions by DOJ, as civil or administrative proceedings by the SEC, as various types of actions by state and foreign enforcement authorities, or as civil actions by private parties. After one of these actions ends in a conviction, a guilty plea, or a finding of liability, the SEC may file a "followon" administrative proceeding to impose an additional penalty. Between 1996 and 2014 , nearly two-thirds of summary dispositions granted for the Division were in these cases.

Delinquent Filings. When issuers are delinquent in their periodic filings, the SEC can bring an AP to suspend or revoke the registration. ${ }^{133}$ The penalty is based in part on an assessment of various factors, including whether the

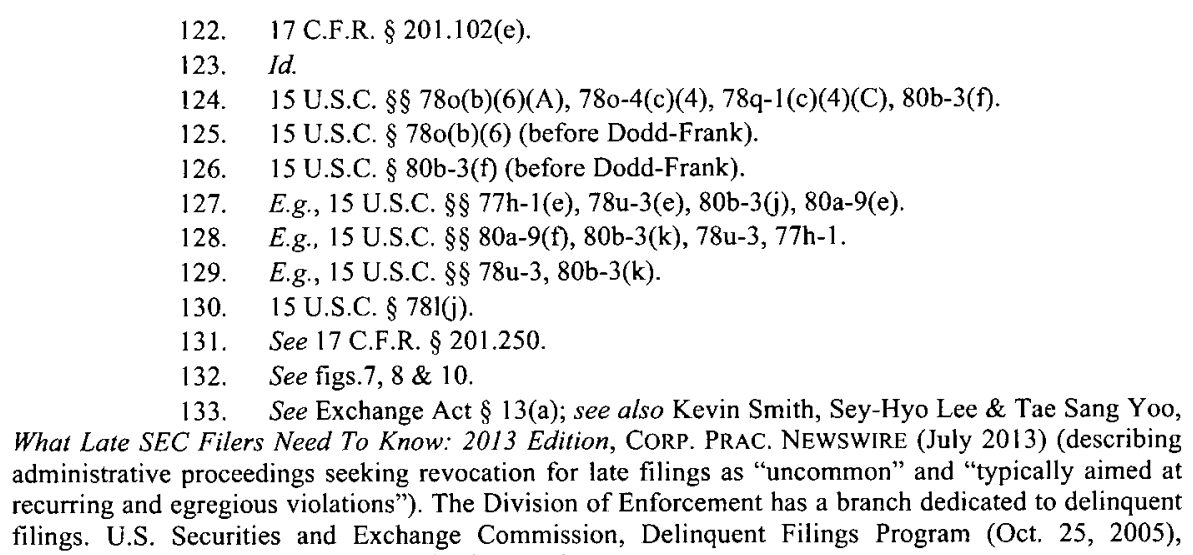

133. See Exchange Act $\S 13(a)$; see also Kevin Smith, Sey-Hyo Lee \& Tae Sang Yoo, What Late SEC Filers Need To Know: 2013 Edition, CORP. PRAC. NEWSWIRE (July 2013) (describing administrative proceedings seeking revocation for late filings as "uncommon" and "typically aimed at recurring and egregious violations"). The Division of Enforcement has a branch dedicated to delinquent filings. U.S. Securities and Exchange Commission, Delinquent Filings Program (Oct. 25, 2005), http://www.sec.gov/divisions/enforce/delinquent.htm. 
issuer is likely to resolve the delinquency. ${ }^{134}$ Between FY 1996-2014, nearly one-third of summary dispositions granted for the Division were in these cases.

Figure 7: Summary Dispositions for Division by Category, FY 1996-2014

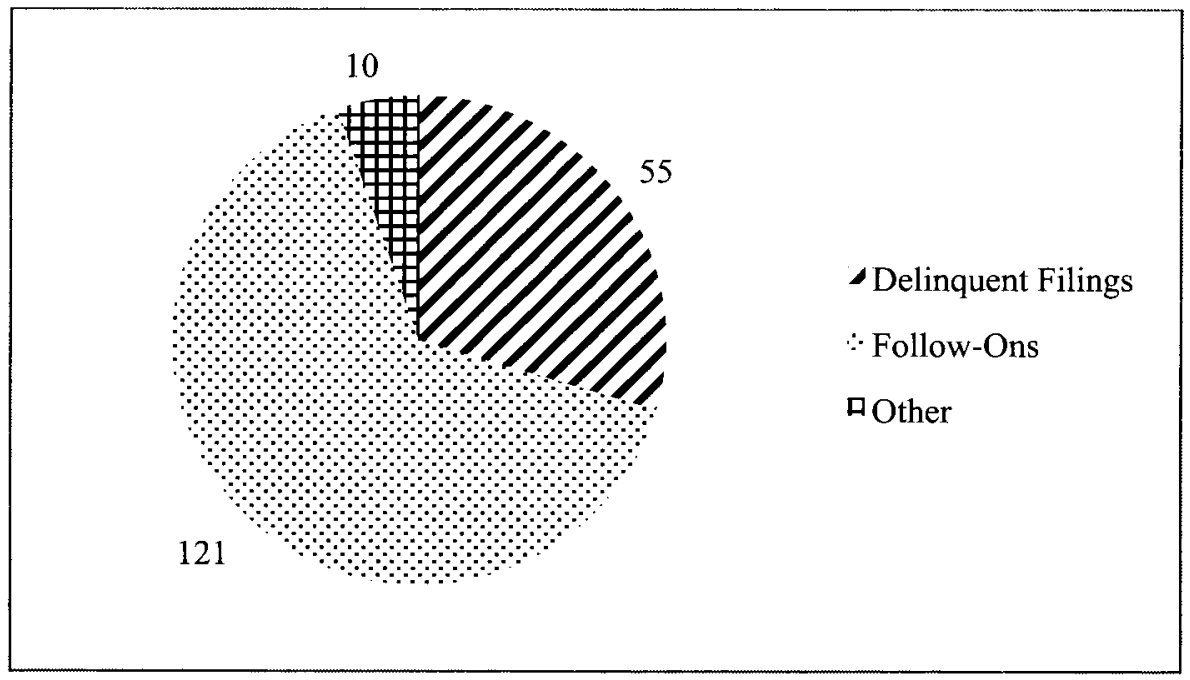

Figure 8: Delinquent Filing Summary Dispositions, FY 1996-2014

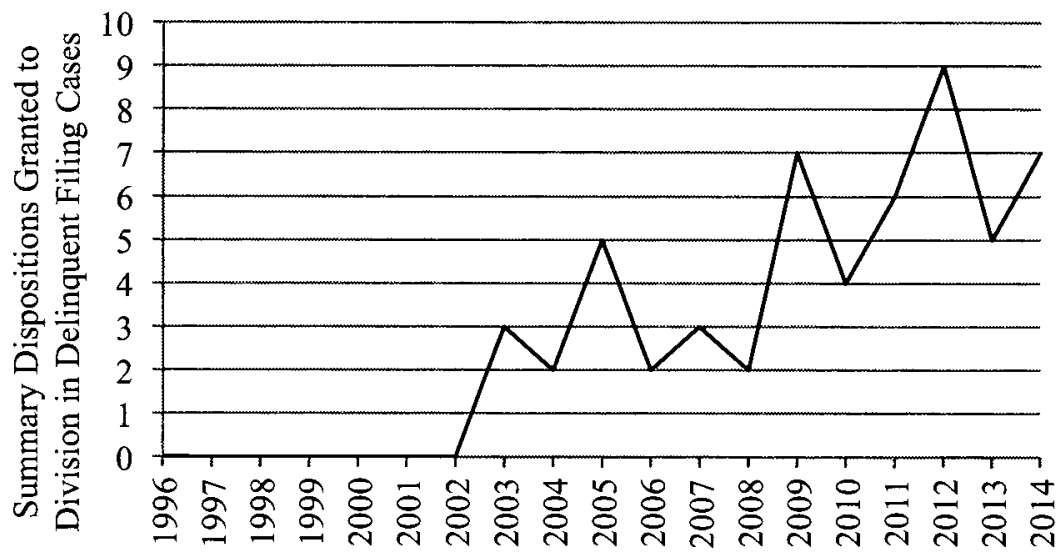

FY grounds, 450 U.S. 91 (1981); see also infra notes 195. 
In July 2016, the SEC adopted certain changes to the Rules of Practice, including changes to the rules governing dispositive motions inside APs. These changes appear calibrated to make these motions modestly more available to Respondents than they have been in the past. ${ }^{135}$ Because these rules do not do anything to temper the Enforcement Division's own use of such motions, ${ }^{136}$ they do not impact the analysis here.

\section{B. SEC Summary Disposition: The Consensus Justification}

Several courts have examined the SEC's use of summary disposition and have upheld the practice by relying on a version of the consensus justification sketched above. $^{137}$ In Kornman v. SEC, the D.C. Circuit upheld summary disposition in a follow-on proceeding, finding the "central issue" (i.e., the underlying violation) had already been resolved by the respondent's prior criminal conviction, and that, on the remaining issues related to his penalty, respondent enjoyed an adequate substitute to a hearing: "the opportunity to challenge the arguments and evidence proffered by the Division . . . by filing an opposition [brief] and filing documents." 138 Similarly, in Gibson v. SEC, another follow-on case, the Sixth Circuit approved summary disposition because the respondent had enjoyed an adequate substitute for a hearing on his penalty: an opportunity to submit mitigating evidence by attaching declarations to his opposition brief-declarations which "both the ALJ and the Commission

135. The new Rules of Practice give parties two new tools with regard to dispositive motions, neither of which was included in the September 2015 proposed rules. First, parties now have the right to file a motion for a ruling on the pleadings to attack the Commission's legal theories underlying the prosecution without seeking leave from the ALJ to do so. See Amendments to the Commission's Rules of Practice, Final Rules at 52, 112-13, SEC Release No. 34-78319, 81 Fed. Reg. 50,212 (July 13, 2016) (adopting new Rule 250(a)). Second, parties can now file interlocutory appeals to the Commission from denials of leave to file a motion for summary disposition. $I d$. at $57 \mathrm{n} .122$. The Commission deserves praise for making these changes, which will give respondents a way to test novel and untested theories of liability when advanced in administrative proceedings. These reforms are similar to ones I proposed in a previous paper. See Platt, supra note 4 (proposing reforms designed to give respondents a realistic way to attack the Commission's legal theories before a neutral adjudicator). However, the Commission rejected other proposals that would have made these motions even more effective tools for respondents. See SEC Release at 50-60.

136. The narrative portion of the Final Rule quietly seeks to cement and confirm the agency's authority to bring Summary Disposition motions in follow-on proceedings-though the rule itself does not do so. 81 Fed. Reg. 50,212, at 50,224 (noting in passing that "we have repeatedly observed that summary disposition is typically appropriate [in follow-on proceedings] because the issues to be decided are narrowly focused and the facts not genuinely in dispute"). As I discuss below, the use of summary dispositions in follow-ons is actually questionable, even through the lens of the Consensus Justification. See infra text accompanying notes 195-199.

137. Kornman v. SEC, 592 F.3d 173 (D.C. Cir. 2010); Gibson v. SEC, 561 F.3d 548 (6th Cir. 2009); Brownson v. SEC, 66 Fed. App'x 687, 688 (9th Cir. 2003).

138. 592 F.3d at 183. 
took ... as true."139 The court found it "difficult to see how live testimony . . would affect the sanctioning determination."

These courts followed the pattern established by earlier cases upholding administrative summary judgment in other contexts. ${ }^{141}$ They evaluate the use of summary judgment in the individual case before them, disregarding any possible programmatic impact on the agency's enforcement priorities. They emphasize the tradeoff between accuracy and costs, disregarding any other possible interests or values embedded in administrative procedure. And they assign primary responsibility to the administrative prosecutor to determine whether a hearing is or is not required, disregarding any possible reasons to doubt that this prosecutor faces structural incentives that prevent him from making this calculation fairly.

\section{SEC Summary Disposition: Unstacking the Deck}

When Congress allocates claims or penalties to an SEC administrative proceeding, it does so with an understanding of the various limits on how broadly those penalties will be enforced, including the agency's enforcement budget, rival agency priorities, and the costs of enforcement. ${ }^{142}$ Recall APA

139. 561 F.3d at 553-54.

140. Id. at 554 .

141. See supra Section I.A. E.g., Weinberger v. Hynson, Wescott \& Dunning, Inc., 412 U.S. 609, 611 (1973) (upholding the FDA's "administrative summary judgment procedure" for hearing regarding withdrawal of agency approval of New Drug Application); United States v. Storer Broad. Co., 351 U.S. 192, 205 (1956) (upholding the rule that the FCC must conduct an oral hearing when denying initial license applications only when the party requesting a hearing has "set forth reasons, sufficient if true, to justify a change or waiver of the Rules"); Chauffeur's Training Sch., Inc. v. Spellings, $478 \mathrm{~F} .3 \mathrm{~d} 117,131$ (2d Cir. 2007) (upholding a paper hearing conducted by the Department of Education for a civil penalty); Crestview Parke Care Ctr. v. Thompson, 373 F.3d 743, 750 (6th Cir. 2004) (upholding a rule "akin to the summary judgment standard contained in Federal Rule of Civil Procedure 56" for HHS civil penalty proceedings); Robbins v. Cyprus Cumberland Coal Co., 146 F.3d 425, 428-29 (6th Cir. 1998) (stating, in passing, that, in the context of a benefits proceeding, there must be an in-person hearing "in person" "absent waiver or a proper grant of a motion for summary judgment"); Puerto Rico Aqueduct \& Sewer Auth. v. EPA, 35 F.3d 600, 604 (1st Cir. 1994) (upholding use of summary disposition procedure, "very similar to the requirement set forth in Rule 56 of the Federal Rules of Civil Procedure" in EPA permit hearings); Veg-Mix, Inc. v. U.S. Dep't of Ag., 832 F.2d 601, 607-08 (D.C. Cir. 1987) (affirming the Agriculture Department's denial of an evidentiary hearing under its procedural rules, which allowed the Department to "dispense with a hearing when no answer is filed," because there was no material issue of fact); Citizens for Allegan Cty., Inc. v. FPC, 414 F.2d 1125 (D.C. Cir. 1969); (authorizing FPC licensing transfer in a hearing conducted with "abbreviated procedure" and explicitly analogizing to FRCP 56).

Courts have also found the right to an in-person hearing was conditioned upon a proper request. Costle, 445 U.S. 198 (upholding EPA's rule conditioning the availability of a hearing on party's "identification of a disputed issue of material fact"); Nat'1 Indep. Coal Operators'Ass'n v. Kleppe, 423 U.S. 388, 399 (1976) (upholding denial formal hearing before assessment of a penalty, finding that a mine operator who failed to request a hearing "in effect voluntarily defaulted and abandoned the right to a hearing"). The cases on SEC Summary Disposition relied heavily on these non-SEC cases. E.g., Kornman, 592 F.3d at 182 (citing Costle, Hynson, Storer, and Puerto Rico Aqueduct).

142. SEC administrative proceedings are species APA formal adjudication. E.g., sources cited supra note 95 . Kornman appears to suggest that hearings under 15 U.S.C. $\S 80$ (b)-3(f) are not governed by the APA. Kornman 592 F.3d at 182. This appears to be wrong. See Steadman v. SEC, 450 U.S. 91 n.13 (1981). 
$\S 556$ (d) which draws a distinction between certain categories of formal proceedings where agencies could avoid hearings "if no prejudice" from others. Since administrative proceedings are neither "rule making" nor "claims for money or benefits" nor "applications for initial licenses," Congress would understand that claims allocated to administrative proceedings would not be exempted from the oral hearing requirement under APA $\S 556(\mathrm{~d}){ }^{143}$ Thus, Congress would have expected that enforcement of that claim would be limited or channeled by those procedural constraints. ${ }^{144}$

By systematically dispensing with these procedures in a subset of cases, the agency's use of summary disposition dispenses with Congress's judgment regarding its enforcement program. Summary judgment unstacks the deck, freeing the agency to pursue an expanded and refocused enforcement program.

This Section analyzes the SEC's summary disposition practice in light of the four indicia listed above. It suggests that the SEC's use of summary disposition provides a case-in-point of Unstacking the Deck.

I-1: Drifting agencies will develop summary judgment programs in response to calls for increased or refocused enforcement.

SEC enforcement is reactive to political forces. ${ }^{145}$ Market crashes generate a public outcry, which, in turn, often produces a political coalition that passes new securities regulation and often bolsters enforcement. ${ }^{146}$

The rise of SEC summary disposition appears to be no exception. The aggressive program of summary disposition may have been a response to calls for expanded enforcement. Though the summary disposition rule was created in 1995 , it was not until 2002, when the agency was grappling with the public and congressional fallout from the Enron scandal, that the agency began its program

143. APA $\S 556(\mathrm{~d})$; see also supra Section I.C. Some administrative proceedings revoke registrations, but that is not "initial licensing." Some administrative proceedings extract civil penalties, but this is not a "claim for money or benefits." But see Chauffeur's Training Sch., Inc., 478 F.3d at 131 .

144. The Securities Laws have been amended many times since the APA was enacted in 1946, including several enactments that expanded the agency's administrative enforcement powers in a number of ways. See, e.g., Platt, supra note 4 (discussing 1990, 2002, and 2010 legislation expanding the SEC's administrative enforcement powers). But each time Congress has expanded the agency's enforcement powers, Congress has also left in place the APA as the procedural architecture governing administrative adjudications at the SEC, and has not purported to alter that regime.

145. E.g., Velikonja, Politics in Securities Enforcement, supra note 105.

146. E.g., Stuart Banner, What Causes Securities Regulation? 300 Years of Evidence, 75 WASH. U. L.Q. 849 (1997); Roberta Romano, Regulating in the Dark, in REGUlatORY BREAKDOWN: ThE CRISIS OF CONFIDENCE IN U.S. REgulation (Cary Coglianese, ed. 2012) [hereinafter Romano, Regulating in the Dark]; see also Roberta Romano, Further Assessment of the Iron Law of Financial Regulation: A Postscript to Regulating in the Dark, ECGI Working Paper Series in Law (Nov. 2014); STEPHEN M. BAINBRIDGE, CORPORATE GOVERNANCE AFTER THE FINANCIAL CRISIS 268-69 (2012) (criticizing "federal bubble laws" intervening in state corporate law as "enacted in a climate of political pressure that does not facilitate careful analysis of costs and benefits," "driven by populist anti-corporate emotions," and "often derived from prepackaged proposals advocated by policy entrepreneurs skeptical of corporations and markets"); PAUL G. MAHONEY, WASTING A CRISIS: WHY SECURITIES REGULATION FAILS 7 (2015) (arguing that "the aftermath of a financial crisis is a bad time to redesign the regulatory framework"). 
of summary disposition. There were many calls for stepped up SEC enforcement. These culminated in new securities legislation, ${ }^{147}$ but this legislation left in place the formal procedural architecture for administrative proceedings-including the statutory limitation on summary adjudication in $\S 556(\mathrm{~d})$. Nevertheless, these developments may have driven the agency to take an aggressive new enforcement approach of using summary adjudication to expand its footprint.

I-2: Drifting agencies will use summary judgment to boost enforcement statistics.

Summary disposition has facilitated the SEC's ability to maximize the number of enforcement actions filed each year. Keeping that number as high as possible-and especially beating last years' number-appears to be a central component of the agency's lobbying platform. ${ }^{148}$ In recent years, the first pages of the agency's annual reports to Congress have proclaimed:

- A "record number of cutting edge enforcement actions" $(2014) ;^{149}$

- "hundreds of enforcement actions" (2013); ${ }^{150}$

- "a near-record number of actions" (2012);

- "more cases than ever previously filed by the Division in a single fiscal year" (2011); ${ }^{152}$

- "the second-highest number of enforcement actions in agency history" (2008).

147. See, e.g., Romano, Regulating in the Dark, supra note 146; Paul S. Atkins \& Bradley J. Bondi, Evaluating the Mission: A Critical Review of the History and Evolution of the SEC Enforcement Program, 8 FORDHAM J. CORP. \& FIN. L. 367, 394-400 (2008).

148. See Jonathan R. Macey, The Distorting Incentives Facing the U.S. Securities and Exchange Commission, 33 HARV. J.L. \& PUB. POL'Y 639, 639 (2010) (explaining that the "SEC's performance is measured by Congress and in the court of public opinion on the simplistic basis of how many cases it brings and on the size of the fines it collects"); see also Velikonja, Reporting Agency Performance, supra note 83, at 911-12 ("Agencies like the SEC are under considerable pressure from Congress to increase their enforcement output year after year without additional appropriations, so perhaps it should come as no surprise that agencies sometimes use fuzzy numbers to meet unreasonable expectations.").

149. U.S. SEC. \& EXCH. COMM'N, FISCAL YEAR 2014 AGENCY FinANCIAL REPORT 2; see also $i d$. at 10 (the agency "ended FY 2014 with 755 enforcement actions . . ..").

150. U.S. SEC. \& EXCH. COMM'N, FISCAL YEAR 2013 AGENCY FINANCIAL REPORT 2; see also id. at 17 ("The SEC ended the fiscal year with 686 enforcement actions, including 402 in the last six months of the year.").

151. U.S. SEC. \& EXCH. COMM'N, FisCAL Year 2012 AgEnCY FinANCIAL REPORT 2; see also id. at 13 ("The SEC brought 734 enforcement actions in FY 2012, the second highest number ever filed in a fiscal year (and one less than the 735 filed the prior year).").

152. U.S. SEC. \& EXCH. COMM'N, FISCAL YEAR 2011 AGENCY FINANCIAL REPORT 2.

153. SEC Announces Fiscal 2008 Enforcement Results, U.S. SEC. \& EXCHANGE COMMISSION (Oct. 22, 2008), http://www.sec.gov/news/press/2008/2008-254.htm. 
Agency leaders have testified before Congress, claiming "the highest number of enforcement actions to date, $755^{\prime \prime}$ in 2015 ; $^{154}$ "686 enforcement actions" in 2014; ${ }^{155}$ and "735 enforcement actions-more than the SEC has ever filed in a single year," in 2012 . $^{156}$

Public speeches ${ }^{157}$ and commentary ${ }^{158}$ by agency leaders reflect a similar emphasis on quantity, as do agency press releases. ${ }^{159}$ The press often echoes the emphasis on the raw total enforcement number. ${ }^{160}$

154. Examining the SEC's Agenda, Operations and FY 2016 Budget Report, Hearing Before the H. Comm. on Financial Servs., 114th Cong. 49 (2015) (statement of Mary Jo White, Chair, SEC); see also Fiscal Year 2016 Budget Request of the U.S. Securities and Exchange Commission, Hearing Before the H. Comm. on Appropriations, Subcomm. on Fin. Services and Gen. Gov't, 114th Cong. 54 (2015) (Statement of Mary Jo White, Chair, SEC) ("The Division of Enforcement continued to achieve significant results, filing 755 enforcement actions ...."); 2016 Budget Request of the U.S. Securities and Exchange Commission, Hearing Before the H. Comm. on Appropriations, Subcomm. on Fin. Services and Gen. Gov't Comm. on Appropriations, 114th Cong. 67 (2015) (statement of Mary Jo White, Chair, SEC) (same); Oversight of the SEC's Division Enforcement, Hearing Before the Subcomm. on Capital Markets and Gov't Sponsored Enterprises of the H. Comm. on Fin. Servs., 114th Cong. 47 (2015) (Statement of Andrew Ceresney, Div. of Enforcement Director).

155. Oversight of the SEC's Agenda, Operations and FY 2015 Budget Request, Hearing before the H. Comm. on Fin. Servs., 113th Cong. 62 (2014) (Statement of Mary Jo White, Chair, SEC).

156. Examining the Settlement Practices of U.S. Financial Regulation, Hearing before the H. Comm. on Financial Servs., 112th Cong. 71 (2012) (Statement of Robert Khuzami, Director, Division of Enforcement); SEC Oversight, Hearing Before the H. Comm. on Fin. Servs., Subcomm. on Capital Markets and Gov't Sponsored Enterprises and Subcomm. on Fin. Institutions and Consumer Credit, 112th Cong. 60 (2012) (Statement of Chairman Mary L. Schapiro); see also Fiscal 2013 Appropriations, H. Comm. on Appropriations, Subcomm. On Fin. Servs. And Gen. Gov't, 112th Cong. (2012) (Statement of Chairman Mary L. Schapiro) (same); Management and Structural Reforms at SEC. A Progress Report, Hearing before the S. Comm. on Banking, Housing, and Urban Affairs, Subcomm. on Securities, Insurance, and Investment, 112th Cong. 174 (2011) (Statement of Robert Khuzami, Director, Division of Enforcement); Implementation of the Wall Street Reform Act, Hearing Before the $S$. Comm. on Banking, Housing, and Urban Affairs, 112th Cong. 86 (2011) (Statement of Mary L. Schapiro, Chairman)

157. Chair Mary Jo White, Chairman's Address at SEC Speaks 2015 (Feb. 20, 2015) ("In 2014, we brought the highest number of cases in the history of the Commission, 755."); Andrew Ceresney, Director of the Division of Enforcement, Remarks to the American Bar Association's Business Law Section Fall Meeting (Nov. 21, 2014) ("In total, we filed 755 actions last year-the mos ever filed in the history of the Commission."); Chairman Mary L. Schapiro, Speech by SEC Chairman: Remarks at 2012 New England Securities Conference (Oct. 11, 2012) (noting that the SEC "brought a record number of enforcement actions in fiscal year 2011"); Robert Khuzami, Director of Division of Enforcement, Remarks Before the Consumer Federation of America's Financial Services Conference (Dec. 1, 2011) ("In fiscal year 2011, the SEC filed a record 735 enforcement actions-a nearly 9 percent increase over the previous year."); Stephen M. Cutler, Director of Division of Enforcement, Remarks Before the American Institute of Certified Public Accountants (Dec. 12, 2002) ("We filed a record number of enforcement actions last year ...."); Stephen M. Cutler, Director of Division of Enforcement, Remarks at the University of Michigan Law School (Nov. 1, 2002) ("We filed a record number of enforcement actions--598, which is more than 100 cases above the previous fiscal year."); Chairman Harvey L. Pitt, Remarks at the Commission Open Meeting (Oct. 16, 2002) ("We've brought a record number of enforcement actions.").

158. SEC Commissioner Elisse B. Walter, Letter to the Editor, The SEC's Triumphs Got Short Shrift, WASH. POST (Oct. 15, 2011) ("[W]e filed a record number of enforcement actions last year.").

159. Press Release, SEC's FY 2014 Enforcement Actions Span Securities Industry and Include First-Ever Cases (Oct. 16, 2014) ("In the fiscal year that ended in September, the SEC filed 
This relentless promotion of the "record number of enforcement actions," year after year, suggests that generating this number is a bureaucratic priority. ${ }^{161}$ Summary disposition is a part of how the agency meets this goal; it allows the agency to bring and close cases without the consent of the defendant - an easy and reliable way to boost the enforcement statistics. ${ }^{162}$

Unfortunately, the total number of enforcement actions is a very poor metric for assessing the impact of SEC's enforcement program. A single "enforcement action" might be the result of an SEC investigation, or a followon action, piggybacking on the investigative work done by another agency. It might target a number of respondents in a large securities conspiracy, or merely be one of many "actions" arising out of the same event or course of conduct. ${ }^{163}$

a record 755 enforcement actions."); Press Release, SEC Announces Enforcement Results for FY 2013 (Dec. 17, 2013) ("The SEC filed 686 enforcement actions in the fiscal year that ended in September."); Press Release, Enforcement Director Robert Khuzami to Leave SEC (Jan. 9, 2013) (announcing that Khuzami led the agency to "the all-time record number of 735 SEC enforcement actions in FY 2011 and another 734 actions in FY 2012"); Press Release, George S. Canellos Named Acting Director of Enforcement (Jan. 31, 2013) ("As Deputy Director, he helped to oversee a division that brought record numbers of enforcement actions ...." (quoting SEC Chairman Elisse B. Walter)); Press Release, SEC's Enforcement Program Continues to Show Strong Results in Safeguarding Investors and Markets: Last Two Years Reflect Two Highest Numbers of Total Actions Brought by SEC (Nov. 14, 2012) ("[T]he Securities and Exchange Commission today announced that it filed 734 enforcement actions in the fiscal year that ended Sept. 30, 2012, one shy of last year's record of 735."); Press Release, SEC Enforcement Division Produces Record Results in Safeguarding Investors and Markets Agency's Fiscal Year Totals Show Most Enforcement Actions Filed in Single Year (Nov. 9, 2011) ("The Securities and Exchange Commission today announced that the agency filed a record 735 enforcement actions in the fiscal year that ended September 30."); Press Release, SEC Announces Fiscal 2008 Enforcement Results Agency Brings Second-Highest Number of Actions Ever; Significant Increase in Insider Trading and Market Manipulation Cases (Oct. 22, 2008), https:/www.sec.gov/news/press/2008/2008-254.htm ("The Securities and Exchange Commission today announced that the second-highest number of enforcement actions in agency history took place in fiscal year 2008."); see also The SEC-Revitalized, Reformed and Protecting Investors, https:/www.sec.gov/news/press/2012/2012-240-accomplishments.htm (praising the accomplishments of Mary L. Schapiro as chair, including that she "[a]chieved [r]ecord [r]esults in [e]nforcement and [i]nspections" and "[b]rought a record number of enforcement actions--including 735 enforcement actions in FY 2011").

160. E.g., Aruna Viswanatha \& Tim Dobbyn, U.S. SEC Enforcement Cases Hit Record High in 2011, REUTERS (Nov. 9. 2011); Rachelle Younglai, Unshackled, Wall Street's Cop Goes Hard on Fraud, REUTERS (Aug. 14, 2009); Andrew Countryman, Securities Regulators Kept Busy Enforcement Staff's Increase Contributed to Year's Record Number of Disciplinary Actions, CHI. TRIBUNE (Jan. 1, 2004).

161. For discussion of these and related arguments, see Velikonja, Politics in Securities Enforcement, supra note 105, at 27-33.

162. See Marc J. Fagel, The State of SEC Enforcement Heading into 2015, 29 INSIGHTS: THE CORPORATE AND SECURITIES LAW ADVISOR No. 2 (Feb. 2015) (suggesting that the Division of Enforcement "clearly is enthusiastic" about the broad prosecution of "broken windows" offenses since it allows them to "announce record-breaking case filings without the same resource expenditures as individual investigations"); Tracey Samuelson, Why the SEC is all about "broken windows, "MARKETPLACE (Sept. 11, 2014) (suggesting that the real purpose of these easy cases is to "help the agency report higher numbers of successful actions" (quoting Michael Rivera, Chair of Securities Enforcement at Venable LLP)). Ironically, the SEC's behavior is analogous to the behavior of companies regulated by SEC, who have manipulated their earnings in order to meet or top previous quarter earnings. See Francois Degeorge et al., Earnings Management to Exceed Thresholds, 72 J. BUS. 1 (1999); see also Robert A. Prentice, The Inevitability of a Strong SEC, 91 CORNELL L. REV. 775, 782 (2006) (citing DeGeorge et al., supra).

163. Fagel, supra note 162 (" 20 of the 755 actions were filed in a single day to stop trading in the securities of multiple purported mining companies controlled by a stock promoter"). 
It might be a groundbreaking case establishing a new point of law or a routine regulatory action. It might culminate in substantial penalties (like lifetime collateral bars and civil penalties) or relatively unimportant ones. ${ }^{164}$

The agency appears to be allocating scarce enforcement resources to the pursuit of a questionable statistic. The agency and its legislative supervisors seem to be looking "where the light is" to evaluate the agency's enforcement program. Perhaps Congress does not understand the problems with the enforcement number. Or perhaps Congress understands the problems, but also knows that the public does not. Most disturbingly, perhaps the agency or Congress is captured by the regulated industry and favors an appearance of active enforcement (to placate voters and Congress) without actually robust enforcement (to placate key players in the industry). ${ }^{165}$

Scholars have often criticized SEC enforcement for bringing a few headline-grabbing cases designed to create a favorable (but inaccurate) impression of its enforcement program. ${ }^{166}$ The emphasis on the number of enforcement actions seems to be another version of the same phenomenon. ${ }^{167}$

The agency has defended its focus on quantity over quality as an implementation of a quasi-"broken windows" theory of law enforcement. ${ }^{168}$ Under that model, "even the smallest infractions have victims, and that the

164. See id: Joshua Gallu, SEC Boosts Tally of Enforcement Successes with Routine Actions, BLOOMBERGBUSINESS (Feb. 22, 2013).

165. See Donald C. Langevoort, The SEC as a Lawmaker: Choices About Investor Protection in the Face of Uncertainty, 84 WASH U. L. REV. 1591, 1600 (2006) ("[W]ell-publicized regulatory action might provide a political buffer from more intrusive 'actual' regulation when scandal or troubles provoke the public.").

166. Langevoort, The SEC as a Lawmaker, supra note 165, at 1600 (““[H]eavy' SEC regulation is often more apparent than real, more dramaturgical than truly burdensome" and "the SEC could be its own purveyor of the illusion that investor protection is of higher quality than it really is."); Adam C. Pritchard, The SEC at 70: Time for Retirement?, 80 NOTRE DAME L. REV. 1073, 1083 (2005) ("[T]he political cycling between policies of benign neglect and hysterical overreaction suggests that SEC far from serving as a shelter against the vagaries of the political winds, acts more like a weathervane, swinging wildly with the change in the political atmosphere."); Robert A. Prentice, The Inevitability of a Strong SEC, 91 CORNELL L. REV. 775, 776 (2006) (referring to the "familiar cycle" where "[1] oose regulation allows for scandal, which then creates a political atmosphere supportive of aggressive regulation, followed by backlash by those regulated"). Some scholars have proposed spinning off the enforcement division as a way to reduce the SEC's accountability to Congress. Pritchard, supra, at 1076; Peter J. Henning, Should the SEC Spin Off the Enforcement Division?, 11 TRANSACTIONS: THE TENN. J. OF BUS. L. 121 (2009).

167. See, e.g., Urska Velikonja, Reporting Agency Performance, supra note 83; Velikonja, Politics in Securities Enforcement, supra note 105, at 33-38; JONATHAN R. MACEY, THE DEATH OF CORPORATE REPUTATION 270-71 (2013); see also LANGEVOORT, SELLING HOPE, supra note 5 , at 45 (describing criticism of SEC enforcement from "the business community" that focuses on "pressure on the enforcement staff to 'make their numbers' by meeting or exceeding expectations about how many cases they close").

168. In October 2013, newly appointed Chair Mary Jo White announced a new enforcement program modeled after the famous "broken windows" theory of policing-i.e., the idea that "when a broken window is not fixed, it "is a signal that no one cares, and so breaking more windows costs nothing." Chair Mary Jo White, Remarks at the Securities Enforcement Forum (Oct. 9, 2013) (quoting James Q. Wilson \& George L. Kelling, Broken Windows, THE ATLANTIC (1982)); see also Prentice, Inevitability, supra note 85 , at 830 (suggesting that "stringent securities laws shape morals and behavior"). 
smallest infractions are very often just the first step toward bigger ones down the road,"169 and so the agency must "pursue all types of wrongdoing" and "not overlook[] the small violations to avoid breeding an environment of indifference to our rules." 170

But this approach is questionable. Even setting aside whether the "broken windows" approach was actually successful in driving down street crime, it is hardly obvious that the same approach would prove successful in combating business crime. ${ }^{171}$

Professor Barkow has defended the "broken windows" approach at the SEC, ${ }^{172}$ but her account does not specifically focus on the prosecution of lowlevel infractions. ${ }^{173}$ She acknowledges that the "broken windows" approach may give enforcers "too much unchecked discretion," but finds that the SEC is adequately "checked" by the oversight that is "built in to the structure of the administrative state," 174 as well as "by an organized, well-financed community if it goes too far with new policing techniques."

Unfortunately, summary disposition allows the agency deliberately to avoid these procedural checks designed to limit its level of enforcement. ${ }^{176}$ And by bringing a large number of relatively minor cases, targeting unrepresented individuals, the agency steers well-clear of the "well-financed" community Barkow describes. ${ }^{177}$

Whether it serves the public interest or not, the agency's pursuit of a large number of low-level offenses appears to be driven, in part, by the availability of administrative summary judgment. ${ }^{178}$

2013).

169. Mary Jo White, Chairman, Remarks at the Securities Enforcement Forum (Oct. 9,

170. Id. Indeed, some have tied the rise in SEC delinquent filing prosecutions - one of the main categories of summary disposition - to the "broken windows" strategy. E.g., Samuelson, supra note 162 (quoting Professor John Coffee as saying that "[b]y forcing stricter disclosure, I think, in turn, you're going to reduce the prospect of insiders exploiting material nonpublic information."); Thomas A. Zaccaro \& Ryan A. Walsh, Attempting to Fix the "Broken Windows": Recent SEC Enforcement Action Targets Routine Disclosure Obligations of Public Corporations and their Insiders, PAUL HASTINGS ALERT (Oct. 2014) ("[I]n policing mere disclosure violations, the SEC has taken yet another step to further its professed 'broken windows' enforcement strategy."); see also Fagel, supra note 162 (suggesting that the Chair's "'broken windows' policy, filing suit to enforce even minor, rarely-enforced provisions of the federal securities laws ... helps explain the record number of cases brought last year").

171. See LANGVEOORT, SElling HOPE, SElLING RISK, supra note 5, at 45-46 (suggesting that it is "doubtful" whether the broken windows model is helpful in white collar crime, and noting the risk of crowding out bigger, harder cases).

172. Rachel E. Barkow, The New Policing of Business Crime, 37 SEATtLE U. L. REv. 435 (2014) enforcement model. $I d$.

173. She focuses on the shift towards a more "proactive" and "intelligence-led"

174. Id. at 465

175. Id. at 467

176. See infra Section I.C

177. See Barkow, New Policing, supra note 172, at 467.

178. Scholars have previously commented on how the desire to deliver the "right" number-i.e., one that is higher than last year's-has skewed SEC enforcement practice towards "low hanging fruit." The Future of Capital Formation, Hearing before the Committee on House Oversight 


\section{I-3: Drifting agencies will use summary judgment to bring more minor} actions and target weaker defendants

The overwhelming majority of summary dispositions are granted in two categories of cases: follow-ons and delinquent filings. These are low-impact cases. While some scholars have noted that the SEC has been bringing more of these types of actions recently, ${ }^{179}$ they have not yet connected this trend to the procedural innovation of summary disposition. Without this novel procedural device, this shift in enforcement would not have been possible. The availability of the procedure has changed the mix of cases brought by the agency.

Almost half of summary dispositions granted for the agency involved at least one respondent who was pro $\mathrm{se}^{180}$ - the kind of individual who might benefit most from an in-person hearing, where the ALJ could ensure he has a chance to make his best case. This is a significantly higher than normal rate of unrepresented respondents: a recent study of SEC ALJ initial judgments from 2010 to 2015 found that respondents were unrepresented about a quarter of the time. ${ }^{181}$ The availability of the procedure seems to be causing the agency to target different types of defendants than it would otherwise.

The more minor cases and minor offenders leave fewer resources for more serious enforcement actions. As Commissioner Piwowar put it: "If every rule is a priority, then no rule is a priority." 182

The SEC has been repeatedly accused of systematically targeting weak respondents in order to serve bureaucratic imperatives. One study found that the SEC targeted more smaller companies (by market capitalization) than did private plaintiffs-a finding the authors found to be "consistent with the hypothesis that the SEC . . . prefer[s] weak opponents." "183 Another found that the SEC was more likely to seek industry bars against smaller firms and their employees. ${ }^{184}$ And, when the SEC sought (and won) large monetary penalties

and Gov't Reform, 112th Cong. (2011) (Statement of Prof. Jonathan Macey); see also JONATHAN R. MACEY, THE DEATH OF CORPORATE REPUTATION 270-71 (2013); LANGEVOORT, SELLING HOPE, supra note 5, at 45; Jonathan R. Macey, Administrative Agency Obsolescence and Interest Group Formation: $A$ Case Study of the SEC at Sixty, 15 CARDOZO L. REV. 909, 949 (1994); Langevoort, The SEC as a Lawmaker, supra note 165 , at 1620.

179. E.g., Velikonja, Politics in Securities Enforcement, supra note 105, at 35-38.

180. See fig.9.

181. See Zaring, supra note 99 , at 1179 .

182. Commissioner Michael S. Piwowar, Remarks to the Securities Enforcement Forum 2014 (Oct. 14, 2014); see also Commissioner Michael S. Piwowar, Remarks at "SEC Speaks" Conference 2015: A Fair, Orderly, and Efficient SEC (Feb. 20, 2015) ("Did you hear that the SEC has invented a new stove? It has fifty front burners.").

183. Cox \& Thomas, supra note 51 , at 764 ; see also id. at 777, 778. But see James D. Cox et al., Public and Private Enforcement of the Securities Laws: Have things Changed Since Enron?, 80 NOTRE DAME L. REV. 893 (2005); cf. Steinway, supra note 105, at 225 (reading the post-Enron shift to bigger companies as a public relations strategy, rather than a genuinely public-interested one).

184. Gadinis, supra note 96 , at 683,685 . There are some arguments that would give justification and support to the SEC pursuing smaller companies. For instance, private securities litigation may be more likely to pursue bigger companies - who are more likely to be willing to settle cases quickly with big payouts to plaintiffs' lawyers-which means the SEC should focus on the smaller 
against issuers, ${ }^{185}$ many complained that these penalties were really borne by the relatively vulnerable (and often innocent) shareholders, rather than the wellfunded managers and directors who were actually responsible, and accused the SEC of seeking favorable headlines at the expense of public interest. ${ }^{186}$ One study showed that SEC was less likely to bring enforcement actions against companies with strong political connections through campaign contributions and lobbying. ${ }^{187}$ Summary disposition appears to continue this trend.

Figure 9: Summary Dispositions for Division by Status of Respondent, FY 1996-2014

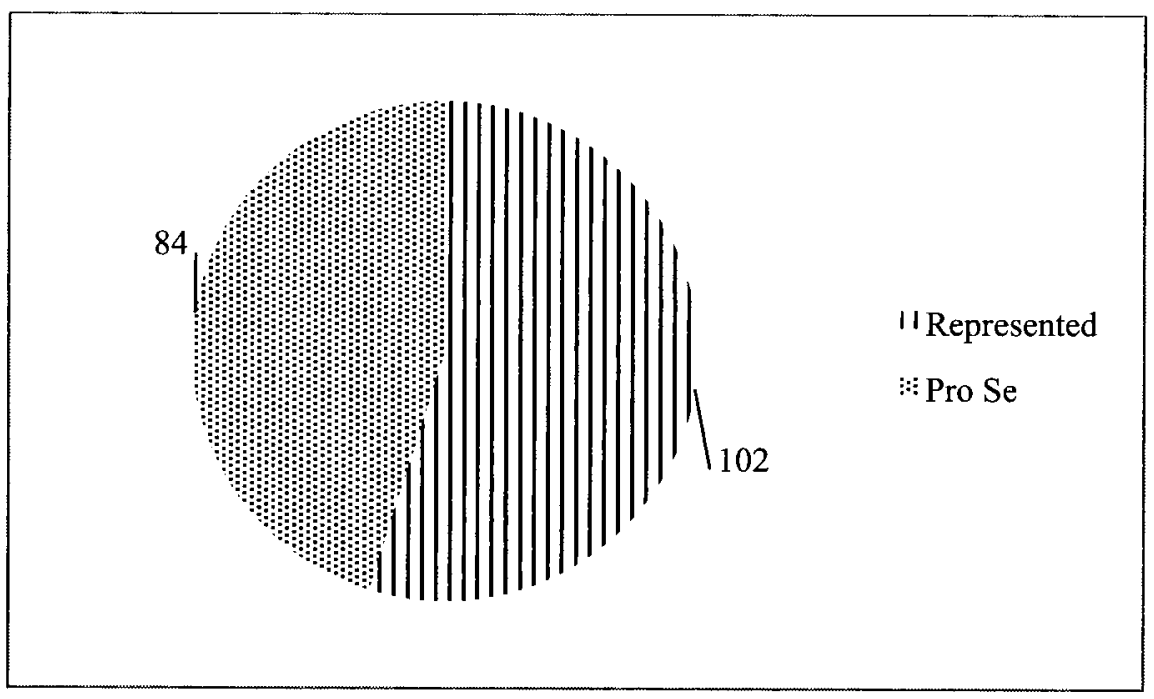

I-4: Administrative prosecutors at drifting agencies will "play for the rules" to develop broad summary judgment programs through case-by-case adjudication, not rulemaking.

ones. Or perhaps the SEC has more faith that it can get the bigger companies to follow the law, and feels the need to clear the misbehaving smaller fish from the industry.

185. The landmark is the Xerox case, in which the company paid a $\$ 10$ million penalty. See Xerox Corp., Litigation Release No. 17465, 77 SEC Docket 971 (Apr. 11, 2002); see also Atkins \& Bondi, supra note 147, at 394. Penalties against issuers have only grown since then. E.g., Steinway, supra note 105 , at 210 .

186. Atkins \& Bondi, supra note 147, at $415-16$ ("The SEC ... faces ... moral hazards when contemplating the assessment of issuer penalties. Does the prospect of large issuer penalties and the inevitable press coverage cause the SEC to misallocate resources to build these cases to the detriment of other types of enforcement actions?'); Steinway, supra note 105 (discussing the "possibility that the SEC will select targets not because they are the worst violators, but for improper reasons such as agency or individual self aggrandizement").

ECON. 241 (2014).

187. Maria M. Correia, Political Connections and SEC Enforcement, 57 J. ACCT. \& 
At first glance, the history of the SEC's program appears not to bear these indicia: the rule authorizing summary disposition was enacted in 1995 via notice and comment rulemaking.

A closer look reveals the opposite. The regulatory history of the 1995 rule reflects a concern with protecting respondents. After the "Remedies Act" of 1990 expanded the SEC's enforcement arsenal inside administrative proceedings, the agency launched a task force to examine and overhaul the rules of procedure to preserve the fairness of the forum. ${ }^{188}$ In its review, the Task Force found that the "apparent reason" for the existing prohibition on dispositive motions prior to the hearing was "the principle that it is the Commission's sole prerogative to determine what matters will be subject to hearing," but if a hearing officer were to dismiss the case before the hearing, he or she would be "overruling the Commission's determination that allegations by the staff warrant a hearing." The Task Force found that this "principle" was "no longer entirely valid" 189 and recommended liberalizing the availability of dispositive motions for respondents. 190

Things have not worked out that way. Statements made during a 2014 hearing by Chief Administrative Law Judge Brenda Murray reveal just how far summary disposition practice has strayed from its administrative origins:

My belief is that when the Commission sets a case down for hearing, and there has been no factual changes between when they made the decision to set it down and when the motion for summary disposition has been filed, that the agency does not want motions for summary disposition granted because you're second-guessing their decision that the case needs to get set down for hearing and that there is a legal basis for it. ${ }^{191}$

188. TASK FORCE REPORT 1-2 (introduction by SEC Chairman Richard C. Breeden, explaining that the Task Force was driven by the 1990 Remedies Act); see also Platt, supra note 4, at 32-35, 38-39 (contrasting this effort at procedural reform with the post-Dodd Frank inaction on this front).

189. See TASK FORCE REPORT 174-75.

190. However, the proposed rule was framed to allow "any party" to make such a motion, $i d$. at 173 , and the Commission adopted this language in its proposed rule, 58 Fed. Reg. 61,732, $61,745-46$. A commentator objected to making the motions available to the Division and proposed make the motion unilateral, but the Commission explained that "the circumstances when summary disposition prior to hearing could be appropriately sought or granted will be comparatively rare" since "[t]ypically, Commission proceedings that reach litigation involve basic disagreement as to material facts." 60 Fed. Reg. 32,738, 32,768 (1995). "Motions for disposition prior to hearing may provide particular benefits in regulatory proceedings. Enforcement or disciplinary proceedings in which a motion for disposition prior to hearing would be appropriate are likely to be less common. Typically, enforcement and disciplinary proceedings that reach litigation involve genuine disagreement between the parties as to material facts." Id. at 32,767 .

191. See In re Anthony et al., SEC File No. 3-15514, Prehearing Conference Tr. 30:13-21 (Jan. 21, 2014); see also Jean Eaglesham, Fairness of SEC Judges Is in Spotlight, WALL ST. J. (Nov. 22, 2015), http://www.wsj.com/articles/fairness-of-sec-judges-is-in-spotlight-1448236970 (quoting CALJ Murray in saying "[s]o for me to say I am wiping it out, it looks like I am saying to these presidential appointee commissioners, I am reversing you. And they don't like that."). 
Chief Judge Murray's statement that a grant of summary disposition for a respondent is inappropriately overruling the Commission runs directly contrary to the 1993 Task Force Report and the 1995 Rules adopting the recommendations of that report. ${ }^{192}$

Instead of announcing a revision of summary disposition rules explicitly through rulemaking, the Division relied on key favorable rulings from ALJs and the Commission to approve its creative and aggressive use of the new motion.

The development of the doctrine surrounding the use of summary disposition in follow-ons reveals how administrative prosecutors are able to drive the development of broad administrative summary judgment programs through case-by-case adjudication.

Follow-on cases involve a respondent who has already been found liable for a securities violation in some other forum. The SEC then brings an action to impose a separate penalty. These may be severe, including monetary fines ${ }^{193}$ and lifetime bars from the industry. ${ }^{194}$ In exercising their discretion to choose an appropriate punishment, $\mathrm{ALJ}_{\mathrm{S}}$ are required to weigh various factors including "the sincerity of the defendant's assurances against future violations," "the degree of scienter involved," and "the defendant's recognition of the wrongful nature of his conduct," and "the likelihood of future violations." 195

These factors seem to be exactly the kind of issues that an in-person hearing would be helpful to elucidate. They require credibility assessments and investigation into facts beyond those required to establish the underlying violation. Indeed, the progenitors of the Consensus Justification for administrative summary judgment, Gellhorn and Robinson, embraced a restriction on summary judgment in cases where "motive and intent play leading roles" or which "involve[d] a question of witness credibility."196 And, several of the leading cases (outside of the SEC) limited approval of administrative summary judgment to issues "precisely" defined, finding it inappropriate for those that "call for the exercise of discretion or subjective judgment." ${ }^{197}$ At least under current doctrine, ${ }^{198}$ these follow-on cases seem to be poor candidates for resolution on the papers. ${ }^{199}$

192. The SEC's recently enacted reforms to the rules of practice appear to override Judge Murray's conclusions by providing that a respondent may move for judgment on the pleadings as of right, in order to challenge the underlying legal theories. See SEC Amendments to the Commission's Rules of Practice, 17 C.F.R. pt. 201 at 52, 112-13 (2016) (adopting new Rule 250(a)).

193. E.g., 15 U.S.C. $\$ \S 77 \mathrm{~h}-1(\mathrm{~g})(1)(\mathrm{B}), 78 \mathrm{u}-2(\mathrm{a})(1), 80 \mathrm{a}-9(\mathrm{~d})(1), 80 \mathrm{~b}-3(\mathrm{i})(1)$

194. E.g., 15 U.S.C. $\S \S 78 \mathrm{o}(\mathrm{b})(6)(\mathrm{A}), 78 \mathrm{o}-4(\mathrm{c})(4), 78 \mathrm{q}-1$ (c)(4)(C), 80b-3(f).

195. Steadman v. SEC, 603 F.2d 1126, 1140 (5th Cir. 1979) aff'd on other grounds, 450 U.S. 91 (1981); see also Blinder, Robinson \& Co. v. SEC, 837 F.2d 1099, 1112 (D.C. Cir. 1988) (rejecting the imposition of a penalty where the agency did not have "before it the full record germane to determining whether [relevant] factors ... were present").

196. Gellhorn \& Robinson, supra note 2, at 614 n.9, 618.

197. Weinberger v. Hynson, Wescott \& Dunning, Inc., 412 U.S. 609, 622 n.17 (1973); Citizens for Allegan Cty., Inc. v. FPC, 414 F.2d 1125, 1129 (D.C. Cir. 1969) (suggesting that administrative summary judgment might be inappropriate for issues "where motive and intent play 
Nevertheless, a few years after the summary disposition rule was created in 1995, SEC prosecutors began seeking summary disposition in follow-on actions. The Commission confronted the question for the first time in 2002. Respondent John Brownson had already pleaded guilty to criminal securities fraud charges when the Enforcement Division commenced an AP, based on the same conduct leading to his guilty plea, seeking to bar him from associating with any broker or dealer. The Division moved for summary disposition, and the ALJ granted the motion. Brownson appealed to the Commission, claiming he was entitled to present his evidence regarding the various penalty factors in a live, oral hearing. The Commission sided with its prosecutors. It conceded that "[s] ummary disposition may not be appropriate in every case," since some follow-on respondents "may present genuine issues with respect to facts that could mitigate his or her misconduct" pursuant to the public interest factors, but held that Brownson (who was a pro se respondent) had "wholly fail[ed] to specify" what evidence he expected to present "or explain how it would establish circumstances, such as rehabilitation or mitigating factors that would counter a determination that it is in the public interest to bar him.",200

This was hardly a blanket approval. Nevertheless, SEC prosecutors ran with it, and (with ALJ acquiescence) began systematically dispensing with hearings in follow-on actions. ${ }^{201}$ And, in a 2007 decision, when the Commission considered the issue again, it established a full-blown presumption in favor of summary disposition for follow-on proceedings. ${ }^{202}$ The Division responded accordingly. ${ }^{203}$

leading roles"); see also Turner, supra note 19, at 732-33 ("Disputes relating solely to historical facts or credibility of testimony generally require a trial to allow confrontation and cross-examination.").

198. Some have proposed that these penalties should be automatic. See, e.g., Velikonja, Reporting Agency Performance, supra note 83, at 963. But, under current law, they are not. Id.

199. Cf. Matthews, supra note 46, at 259-60 ("Since the Commission must tailor its sanction to comply with public interest criteria, character witness testimony can constitute a crucial underpinning of a respondent's trial strategy. In this respect, trial of the administrative proceeding resembles criminal litigation much more than routine civil litigation."). When scholars describe followons as "strict liability" offenses, this is actually misleading: the determination of liability is on the basis of strict liability, but the penalty is not.

200. In re John S. Brownson, SEC Release No. 46161, at 11-12 (Commission, July 3, 2002).

201. For instance, in a 2003 case, a respondent opposed the Division of Enforcement's motion for summary disposition in a follow-on proceeding, seeking an opportunity for a hearing on Steadman factors "such as the egregiousness of his conduct and his scienter," but the ALJ granted summary disposition (citing Brownson) and held that the respondent had an adequate opportunity to present his evidence regarding these factors in his pleadings, which (pursuant to the rule) would be "taken as true." In re Callipari, Admin Proceeding No. 3-11205, Release No. 237 (Initial Decision, Sept. $30,2003)$.

202. In the Matter of Conrad P. Seghers, Admin. Proceeding No. 3-12433, Release No. 2656 (Commission, Sept. 26, 2007) ("For a follow-on proceeding, summary disposition may be inappropriate in certain rare circumstances when a respondent may present genuine issues with respect to facts that could mitigate his or her misconduct.").

203. See fig.10. 
Figure 10: Summary Dispositions in Follow-On Proceedings, FY 1996-2014

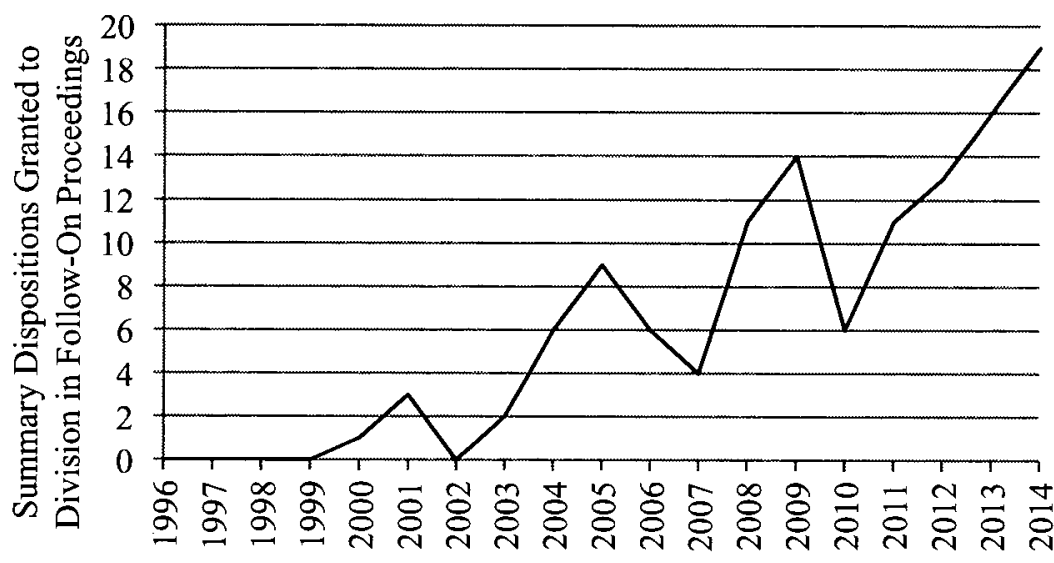

FY

The SEC's prosecutors obtained favorable interpretations of the agency's procedural rules that it then magnified and used to its advantage. Perhaps these prosecutors benefited from their repeat player effect, and their ability to "play for the rules." 204 Or, perhaps they benefitted from ALJ bias. ${ }^{205}$ Either way, the extremely liberal rules now governing the Division's use of summary disposition feeds into the suspicion that administrative proceedings are fundamentally "rigged" against respondents, and the SEC has a "home court

204. See supra note 37.

205. There is some evidence that SEC's ALJs feel pressure to rule for the agency. In May 2015, the Wall Street Journal published a report based on an interview of a former SEC ALJ (Lillian McEwan) who claimed that, while on the bench, Chief ALJ Brenda Murray criticized her for ruling against the agency, questioned her "loyalty to the SEC," and pressured her to rule in favor of the agency more often. Jean Eaglesham, SEC Wins with In-House Judges, WALL ST. J. (May 6, 2015) http://www.wsj.com/articles/sec-wins-with-in-house-judges-1430965803. Ms. McEwan explained that, while an ALJ, she felt that she was "expected to work on the assumption that "the burden was on the people who were accused to show that they didn't do what the agency said they did."' $I d$. This report led one group of respondents to seek discovery regarding the possible bias of the ALJ hearing their case, Cameron Elliot. The Commission responded with an order "inviting" the ALJ in question to file an affidavit "addressing whether he has had any communications or experienced any pressure similar to that alleged in the ... Wall Street Journal article ... and whether he is aware of any specific instances in which any other Commission ALJ has had such communications or experienced such pressure. Order Concerning Additional Submission and Protective Order, In Re Timbervest, Admin. Proceeding No. 315519, IAA Release No. 4103, ICA Release No. 31660 (June 4, 2015); see also Jean Eaglesham, SEC Judge Declines To Submit Affidavit of No Bias, WALL ST. J. (June 11, 2015), http://blogs.wsj.com/moneybeat/2015/06/11/sec-judge-declines-to-submit-affidavit-of-no-bias (quoting professor Kent Barnett as describing the request as "unprecedented" and "bizarre"). Judge Elliott declined to file the affidavit without comment. Eaglesham, SEC Judge, supra. The SEC's Inspector General cleared Judge Murray of any impropriety. See SEC Office of Inspector General, Report of Investigation Case \# 15-ALJ-0482-I (Jan. 21, 2016). 
advantage"206 - suspicions which have fueled a backlash against the agency, culminating in several pending legal challenges. ${ }^{207}$

The SEC's use of Summary Disposition appears to bear the hallmarks of "drift." Whereas the Consensus Justification imagines the agency's prosecutors making individualized case-by-case determinations about which hearings would be "futile," the procedure seems to have impacted the agency's enforcement program in a much broader way. It has facilitated a shift towards easy-to-prosecute offenses, against less-well-represented targets, in order to pursue questionable statistical goals set by Congress. At the same time as it has shaped their enforcement priorities, SEC prosecutors appear to have aggressively sought and attained broader and broader definitions of the administrative summary judgment rule.

\section{Implications}

The Unstacking the Deck theory raises questions and issues about administrative summary judgment that the Consensus Justification cannot address. This part surveys implications for scholars, courts, ALJs, Congress, agencies, and the SEC.

\section{A. Scholars}

Agency decisions about enforcement priorities constitute an important part of the regulatory landscape. ${ }^{208}$ Yet as compared to rulemaking or adjudication, these programmatic enforcement decisions have remained relatively insulated, not only from judicial review, ${ }^{209}$ but also from academic study. ${ }^{210}$

206. See generally sources cited supra note 100. Concerns about SEC neutrality have been raised in the past. See ABA Comm. on Fed. Regulation of Sec., Report of Task Force on the SEC Administrative Law Judge Process, 47 Bus. LAw.1731, 1734 (1992).

207. The agency has recently attempted to quietly confirm its authority to bring summary disposition in follow-on cases by referring, in passing, to this authority in recently promulgated amendments to its rules of practice. See supra note 136.

208. See supra note 33.

209. See, e.g., Andrias, supra note 33, at 1043; Barkow, Overseeing Agency Enforcement, supra note 32, at 102 ("Most aspects of agency enforcement policy generally escape judicial review .... . Courts tend to steer clear of second-guessing an agency's selection of which actors to target and which to ignore."); Lemos, supra note 32, at 45 ("Nor will courts second-guess the government's decisions to enforce or not to enforce.").

210. Andrias, supra note 33, at 1033-34 ("[Scholars have ... undertaken remarkably little analysis of the President's role in agency enforcement."); Barkow, Overseeing Agency Enforcement, supra note 32, at 103-04 (noting that administrative enforcement policy has received "insufficient attention"); Lemos, supra note 32, at 13 (noting that administrative enforcement remains "remarkably under-theorized"); Zachary S. Price, Enforcement Discretion and Executive Duty, 67 VAND. L. REV. 671, 678 (2014) ("[U]ntil recently the ... issue of policy-based nonenforcement attracted only a few relatively brief and impressionistic treatments."). 
This is changing. ${ }^{211}$ In recent years, scholars have explored many different aspects administrative enforcement policy, including presidential control, ${ }^{212}$ the distinct issues presented by decisions not to enforce, ${ }^{213}$ and the roles of institutional design, ${ }^{214}$ management and training strategies, $^{215}$ financial incentives, ${ }^{216}$ and agency reporting statutes ${ }^{217}$ in shaping enforcement priorities. Scholars have also explored various philosophical and theoretical foundations for enforcement. ${ }^{218}$ Finally, scholars have evaluated various proposals such as subjecting enforcement decisions to cost/benefit analysis, ${ }^{219}$ OIRA-style centralized review, ${ }^{220}$ a sentencing commission, ${ }^{221}$ insulating enforcement decisions from judicial review using the political question doctrine, ${ }^{222}$ and taking all enforcement authority away from specialized agencies and reassigning it to generalist enforcers. ${ }^{223}$

However, this growing literature of administrative enforcement has overlooked a critical input into enforcement decision making: administrative adjudication procedure. This Article has shown that adjudication procedure can drive enforcement priorities, and can serve as a site for competing political agendas between the enacting Congress, the agency, the regulated industry, and the current Congress. Moreover, as elaborated in the next section, procedure and procedural developments can serve as an indirect avenue for judicial

211. See Max Minzer, Should Agencies Enforce?, 99 MINN. L. REV. 2069, 2074 (2015) ("How administrative agency enforcement should be structured is beginning to receive considerable academic attention.").

212. See, e.g., Andrias, supra note 33.

213. Zachary S. Price, Reliance on Nonenforcement, 58 WM. \& MARY L. REV. (forthcoming 2017); Zachary S. Price, Politics of Nonenforcement, 65 CASE W. L. REV. 1119 (2015); Price, Enforcement Discretion and Executive Duty, supra note 210.

214. Barkow, Overseeing Agency Enforcement, supra note 32; Rachel E. Barkow, Insulating Agencies: Avoiding Capture Through Institutional Design, 89 TEX. L. REV. 15 (2010); Rachel E. Barkow, Institutional Design and the Policing of Prosecutors: Lessons from Administrative Law, 61 STAN. L. REV. 869, 871 (2009).

215. Stephanos Bibas, Prosecutorial Regulation Versus Prosecutorial Accountability, 157 U. PA. L. REV. 959 (2009).

216. E.g., Margaret H. Lemos \& Max Mnizner, For-Profit Public Enforcement, 127 HARV. L. Rev. 853 (2014); Christopher C. DeMuth Sr. \& Michael S. Greve, Agency Finance in the Age of Executive Government, George Mason U. L. \& Econ. Research Paper Series 16-25 (2016).

217. Velikonja, Reporting Agency Performance, supra note 83.

218. See Lemos, supra note 32; Max Minzner, Why Agencies Punish, 53 WM. \& MARY L. REV. 853 (2012); Margaret H. Lemos \& Alex Stein, Strategic Enforcement, 95 MinN. L. ReV. $9(2011)$.

219. J.W. Verret, Economic Analysis in Securities Enforcement: The Next Frontier at the SEC, 82 U. CINCINNATI L. REV. 49 (2013).

220. Andrias, supra note 33, at 1077-1107.

221. Max Minzner, A Sentencing Commission for the Administrative State?, 103 GEO. L. J. ONLINE 87 (2015).

222. Zachary S. Price, Law Enforcement as Political Question, 91 NotrE DAME L. REV. 1572 (2016).

223. Minzner, Should Agencies Enforce?, 99 MINN. L. REV. 2069 (2015); see also Adam C. Pritchard, The SEC at 70, supra note 166 (evaluating whether the SEC should spin off the enforcement division); Henning, supra note 166. 
review into agency enforcement priorities. As scholars continue to study administrative enforcement, they should not overlook the role of procedure.

\section{B. Courts}

Deck-stacking theorists have struggled to provide a satisfactory account of the role of courts in setting administrative procedures. Early articulations assumed courts would act as "faithful agents" to the original legislative coalition; ${ }^{224}$ deck-stacking procedures could only achieve their political ends if agencies actually adhered to them, and it was left to courts to ensure they did so.

The notion that courts ought to respect the decision of the enacting Congress (as crystalized in statutory text) over and above conflicting positions of a subset of the contemporary Congress or administrative agency, is now a broadly accepted principle in the lawyerly world. ${ }^{225}$ But, as a descriptive matter, courts plainly do not always do this-they do not always act as faithful agents to the enacting Congress, and instead often interpret substantive and procedural statutes in ways that would have been unimaginable to their drafters. ${ }^{226}$ As a matter of theory (if not doctrine), departing from the enacting Congress's views may or may not be the right thing to do. ${ }^{227}$

Theorists quickly proposed alternatives to the faithful agent model for courts. Some argued that courts enforced procedural devices as written in order to avoid legislative reprisal. ${ }^{228}$ But then scholars showed that the fear of reprisal is not realistic. ${ }^{229}$ Moreover, if true, it would undermine the entire positive theory of administrative procedure: courts would choose procedures to satisfy current legislative majorities, not the enacting ones.

Professor Jonathan Macey has proposed that courts designed civil procedure to give themselves the ability to resolve cases outside their areas of

224. E.g., Bressman, supra note 25, at 1772 ("Positive political theorists have not looked across the whole spectrum of administrative law .... At most, they have assumed that the Court would produce principles to assist Congress in monitoring agencies." (emphasis added)).

225. See Jane S. Schacter, Text or Consequences?, 76 BRoOK. L. REV. 1007, 1008 \& n.7 (2011) (observing that it has become common for scholars to proclaim that "we are all textualists now" and collecting sources).

226. See WILLIAM N. ESKRIDGE, JR., DYNAMIC STATUTORY INTERPRETATION (1994); Bressman, supra note 25.

227. The literature on the theoretical justifications and drawbacks of competing modes of statutory interpretation is vast. For one starting place, compare ESKRIDGE, supra note 226, with ANTONIN SCALIA, A MATTER OF INTERPRETATION: FEDERAL COURTS AND THE LAW (Amy Guttmann ed., 1997). For one overview, see Abbe Gluck, The States as Laboratories of Statutory Interpretation: Methodological Consensus and the New Modified Textualism, 119 YALE L.J. 1750, 1761-70 (2010).

228. See McNollgast, Conditions for Judicial Independence, 15 J. CONTEMP. LEGAL ISSUES 105, 114-15 (2006) (suggesting that courts will formulate doctrines to minimize the possibility of legislative reversal); see also Bressman, supra note 25, at nn.137-38 (collecting sources).

229. See Jeffrey A. Segal, Separation-of-Powers Games in the Positive Theory of Congress and Courts, 91 AM. POL. SCI. REV. 28, 42 (1997). 
substantive expertise on technical procedural grounds. ${ }^{230}$ But this explanation does not offer much help in the context of administrative adjudicatory procedure-authorizing summary judgment for the ALJ inside the agency does not significantly change the dynamics of review for the circuit court.

More generally, political scientists explain judicial behavior through some function of, inter alia, ideology and leisure-preference. ${ }^{231}$ But ideology seems an unlikely explanation for administrative procedural decisions: whatever procedural rule is applied in a given case is likely to carry over to many others in diverse contexts. And, allowing administrative summary judgment saves significant time for the agency, but not much for the appellate court, which still must review the decision. In fact, by allowing the agency to bring and litigate more cases, it means more cases will be appealed to courts for review.

Professor Lisa Bressman argues that courts' overarching interest in construing the APA is not in acting as a faithful agent to Congress, but rather in preserving their role as "mediator" between both political branches. ${ }^{232}$ This leads the courts to make decisions based on a tradeoff between two competing considerations: "the need for legislative monitoring" and the "concern for judicial overreaching.,"233 On one side of the equation are the informational and other interests identified by deck-stacking theorists. On the other side, the fear of generating a new principal-agent problem for Congress to worry about.

Though she does not frame it in these terms, Bressman's theory seems to be a hybrid between the Consensus and the Unstacking approaches. Consider Bressman's application of her "mediation" theory to two key cases cutting back (or declining to extend) procedural obligations in the rulemaking context: Vermont Yankee and Florida East Coast Railway. In both cases, Bressman argues, the Court declined to require additional layers of procedures because the existing ones provided a sufficient measure of political control and requiring additional ones might have appeared to be a "judicial overreach.,"234 The Court made a determination that, on the one hand, the political control served by those procedures was adequately served by other procedures, and on the other hand, going farther would risk diminishing the judiciary's role as "mediator."

But in upholding summary judgment, courts have demonstrated no awareness of the political control side of Bressman's equation-i.e., the programmatic or political dynamics of their decisions. ${ }^{235}$ They have not demonstrated any recognition that agencies might use summary judgment to

230. Jonathan R. Macey, Judicial Preferences, Public Choice, and the Rules of Procedure, 23 J. LEGAL. STUD. 627, 630 (1994).

231. E.g., Lee Epstein, Richard Posner \& William Landes, The Behavior of FEDERAL JUDGES (2012).

232. Bressman, supra note 25 , at 1774

233. Id. at 1775 .

234. Id. at 1784-85.

235. See supra Sections I.A, III.B. 
shift enforcement priorities, or that they will do so in a manner that constitutes "drift" away from enforcement choices made by the original enacting Congress. Thus, if they are truly "mediating," they are doing a very one-sided job of it.

At bottom, therefore, broad judicial approval of administrative summary judgment appears to be, at least in part, an artifact of courts' lack of attention to the downstream effects of procedural rulings on the agency's enforcement programs. Before courts approve an individual deployment of summary disposition inside a regime of formal APA adjudication, they should consider questions posed by the Unstacking the Deck theory. When Congress imposed this adjudication structure, did it evince an intent to make enforcement expensive and thereby limit or channel the agency's enforcement program? Will approving this procedure lead the agency to change its enforcement priorities towards certain categories of cases or defendants, and away from others? If the procedure is approved in some limited categories of cases, will agency prosecutors respect those boundaries, or will they be likely to push to expand them over time? To date, scholars have overlooked the programmatic effects of administrative summary judgment, or the way it intersects with the enacting Congress's intent for the agency's enforcement program. This academic shortfall has left litigants and courts without an adequate basis for conducting Bressmanian mediation.

\section{C. $A L J S$}

For some targets of administrative summary judgment, taking an appeal up to the reviewing appellate court is simply too costly, and too slow. For these defendants, making the procedural case against administrative summary judgment before an ALJ will be their first and only chance. However, ALJs do not have free reign to reconsider legal issues like the legality of administrative summary judgment. At the SEC, for instance, ALJs are bound to follow the precedents of Commission opinions-including those approving of broad summary judgment practice. That is not to say that ALJs are powerless in monitoring these procedural developments. For example, an ALJ who is sympathetic to the arguments laid out in this paper against summary judgment could acknowledge the precedent binding them, but issue an opinion calling it into question, and certify the issue for interlocutory appeal to the commission or other reviewing body.

\section{Congress}

The Unstacking the Deck lens shows that Congress plays an important role in limiting or channeling agency enforcement priorities by designing administrative procedure. But Congress can also incentivize drift. As discussed above, the SEC's quantity-over-quality based enforcement approach seems to 
be driven by a desire to annually demonstrate "record" enforcement numberssomething Congress apparently values.

If Congress believes that this quantitative approach is truly consistent with the public interest, it should consider amending the appropriate statutes to authorize summary judgment. It could amend APA $\S 556(d)$ to strike the specific exception for "licensing" and "benefits" cases, and provide for a general exception to the hearing requirements for any case where there is no genuine issue of material fact. More narrowly, it could amend the specific organic statutes for each particular agency to provide for summary judgment in some or all cases.

But if Congress has doubts about this approach, it ought to stop incentivizing agencies to skew their enforcement priorities simply to generate potentially meaningless data. It should adjust its policies regarding what data agencies are required to present - and should actively discourage agencies from even presenting enforcement data that are not meaningfully linked to enforcement effectiveness. ${ }^{236}$

\section{E. Agencies}

The availability of administrative summary judgment has the potential to skew agency enforcement priorities towards those cases that happen to be most amenable to this procedure-even if they are not the best use of the agency's resources. This means bringing more, simpler cases against less well-funded defendants, and foregoing the more difficult, and possibly more important, cases.

Executive branch leaders have a duty to ensure that enforcement priorities are chosen based on the public interest, and to resist changes in enforcement priorities that are driven by factors other than the public interest. ${ }^{237}$ If the changes in priorities that are driven by the availability of summary judgment are not in the public interest, agencies should resist these changes.

Agencies should consider producing guidelines that lay out in detail when and how they will seek summary judgment. These guidelines themselves would likely not be directly subject to judicial review, but their existence would facilitate judicial review of enforcement programs by giving an individual the power to draw the court's attention to programmatic issues inside an individual challenge to a case resolved on summary judgment. ${ }^{238}$

236. See Velikonja, Reporting Agency Performance, supra note 83, at 970-77 (proposing specific reforms to the legislative reporting mandates).

237. See Lemos, supra note 32 , at 20 ("Whereas private enforcers focus on private costs and benefits, public enforcers can take account of the broader social consequences of the case, including costs and benefits to defendants, third parties, and the system as a whole.").

238. For related proposals that agencies should bolster transparency of their enforcement priorities, see Lemos, supra note 32 , at $48-53$ ("[E]nforcement policy ought to be articulated before the fact, both to inform the public and to create opportunities for input."); and 


\section{F. The SEC}

Thanks to the aggressive creativity of SEC prosecutors, and the acquiescence of ALJs, the SEC now systematically applies summary judgment in cases where it seems to be inappropriate even under the Consensus Justification. In follow-on cases, the agency is now presumptively entitled to summary disposition not only as to liability (which cannot reasonably be contested), but also as to the penalty, which is supposed to be based on a holistic evaluation of various factors including several related to the mental state of the accused. ${ }^{239}$ These factors are poorly suited for resolution on the papers, as even the progenitors of the Consensus Justification recognized. ${ }^{240}$

The SEC should consider implementing a hybrid procedure for follow-on actions; utilizing summary disposition for liability, while allowing a hearing as to the penalty. It could promulgate informal guidance outlining this procedure for follow-on cases, which is likely available already under the rules which allow for parties to seek partial summary disposition. ${ }^{241}$ Scholars could help push the agency in this direction if they can demonstrate that the penalties doled out in cases resolved on summary disposition were systematically more severe than those where the respondent was allowed to appear in person before the ALJ. (Such proof would be likely difficult to provide with any degree of precision because of selection effects.)

Given the SEC's commitment to the view that an in-person hearing would not make a difference as to penalty in follow-on cases, it should be willing to facilitate an effective test of this proposition. The agency should conduct an experiment: where the penalty phases of follow-on cases that the agency would have assigned to summary disposition would be randomly assigned either to summary disposition or to an in-person hearing. (A respondent randomly assigned to summary disposition would have nothing to complain about from the experiment since he would have been assigned to summary disposition anyway.) Evidence that in-person hearings have no effect on penalty would support the SEC's current position; evidence to the contrary would require it to reevaluate its policy on summary disposition.

\section{Conclusion}

Administrative Summary Judgment rests on an incomplete therretical foundation. Scholars, agencies, and courts have concluded that costly statutory hearings can be justifiably dispensed with where they would noc enhance accuracy. But administrative procedure is not merely an instrurinent to be

\footnotetext{
Andrias, supra note 33 , at 1078 ("[E]nforcement policy should involve a greater measure of transparency -not of deliberation, but of the ultimate decisions made.").

239. See supra Section III.C.

240. See supra text accompanying notes 195-199.

241. 17 C.F.R. $\$ 201.250$ (2016).
} 
expertly calibrated by agency prosecutors in individual cases; it is a mechanism of congressional control over the bureaucracy. When the SEC uses summary disposition to transform its enforcement priorities, it is breaking free of procedural controls imposed by the enacting Congress - for better or for worse. Many enforcement agencies employ some version of administrative summary judgment. ${ }^{242}$ Additional work is needed to determine whether these other agencies reflect the same issues as the SEC's use of the procedure.

For members of a regulated industry, an agency's enforcement priorities are critically important-particularly where the underlying potentially enforceable legal obligations are vast, complex, and/or vague. These priorities are similarly important for investors, consumers, or other intended beneficiaries of administrative enforcement programs. The effectiveness of the regulatory program depends on effective enforcement, and the effectiveness of enforcement depends on choosing the right set of actions to bring. ${ }^{243}$ As scholars continue to explore various aspects of administrative enforcement, they should not overlook the role that administrative procedure plays in shaping enforcement priorities, both as a vehicle for congressional control and a site for administrative rebellion.

242. E.g., 10 C.F.R. $\S 2.749$ (NRC); 16 C.F.R. $\S 3.24$ (FTC); 21 C.F.R. $\S 12.93$ (FDA); 47 C.F.R. $\$ 1.251$ (FCC); 40 C.F.R. $\$ \S 22.20$, 124.75, 164.91 (EPA); 29 C.F.R. 102.35(h) (NLRB); 29 C.F.R. $\S 2200.2$ (OSHA). I explore these other agencies' summary judgment practices in a separate paper.

243. See, e.g., Minzner, Should Agencies Enforce?, supra note 223 (arguing that enforcement expertise is a distinct form of expertise, separate from an agency's expertise in its subject area). 